\title{
Fermentative production of butyric acid from wheat straw: Economic evaluation
}

\author{
Baroi, G. N.; Gavala, Hariklia N.; Westermann, P.; Skiadas, loannis
}

Published in:

Industrial Crops and Products

Link to article, DOI:

10.1016/j.indcrop.2017.04.008

Publication date:

2017

Document Version

Peer reviewed version

Link back to DTU Orbit

Citation (APA):

Baroi, G. N., Gavala, H. N., Westermann, P., \& Skiadas, I. (2017). Fermentative production of butyric acid from wheat straw: Economic evaluation. Industrial Crops and Products, 104, 68-80.

https://doi.org/10.1016/j.indcrop.2017.04.008

\section{General rights}

Copyright and moral rights for the publications made accessible in the public portal are retained by the authors and/or other copyright owners and it is a condition of accessing publications that users recognise and abide by the legal requirements associated with these rights.

- Users may download and print one copy of any publication from the public portal for the purpose of private study or research.

- You may not further distribute the material or use it for any profit-making activity or commercial gain

- You may freely distribute the URL identifying the publication in the public portal

If you believe that this document breaches copyright please contact us providing details, and we will remove access to the work immediately and investigate your claim. 
Crops and Products

Elsevier Editorial System(tm) for Industrial

Manuscript Draft

Manuscript Number: INDCRO-D-16-03637R2

Title: Fermentative production of butyric acid from wheat straw: economic evaluation

Article Type: Research Paper

Section/Category: Biorefinery, valorization of byproducts

Keywords: Economic analysis;

Wheat straw;

Butyric acid;

Fermentation;

C. tyrobutyricum;

Electrodialysis

Corresponding Author: Dr. Ioannis V. Skiadas, PhD

Corresponding Author's Institution: Technical University of Denmark

First Author: George Baroi

Order of Authors: George Baroi; Hariklia Gavala; Peter Westermann;

Ioannis V. Skiadas, PhD

Abstract: The economic feasibility of biochemical conversion of wheat straw to butyric acid was studied in this work. Basic process steps included physicochemical pretreatment, enzymatic hydrolysis and saccharification, fermentation with in-situ acids separation by electrodialysis and product purification. Two scenarios (S1 and s2) were examined assuming a plant with an annual capacity of 10,000 tonnes of product installed in India (due to significantly lower feedstock prices). S1 resulted in a product of 89\% butyric acid mixed with acetic acid and S2 produced butyric acid of 99\% purity. Unit production cost was estimated at 2.75 and 3.31 s per $\mathrm{kg}$ product for S1 and s2 respectively. The main part of production cost was attributed to steam for the purification step and electricity for the in-situ acids separation. This unit production cost combined with an estimated butyric acid selling price (year 2014) at 3.50 and 3.95 \$ per kg product (for S1 and S2 respectively) and a plant capacity of 10,000 tonnes indicated an internal rate of return of $14.92 \%$ and $12.42 \%$ and payback time of 4.28 and 4.70 years for S1 and S2 respectively. Sensitivity analysis showed that under the assumptions of the present study the optimum plant capacity would lie between 10,000 and 15,000 tonnes of product per year. 
- High yield of butyrate ( $0.45 \mathrm{~g} \mathrm{~g}^{-1}$ sugar) can be achieved from fermentation of wheat straw

- In-situ acids separation by electro dialysis is necessary to secure high yields

- Butyrate production from straw is economically viable for big enough plant capacities

- The optimum plant capacity lies between 10 and 15 million $\mathrm{kg}$ of product per year

- Estimated unit production cost is around $3 \$ / \mathrm{kg}$ and payback time less than 5 years 
Fermentative production of butyric acid from wheat straw: economic evaluation

\section{Abstract:}

\author{
G.N. Baroi ${ }^{\mathrm{a}}$, H.N. Gavala ${ }^{\mathrm{b}}$, P. Westermann ${ }^{\mathrm{a}}$ and I.V.Skiadas, ${ }^{\mathrm{b}, *}$
}

\begin{abstract}
a Aalborg University, Department of Chemistry and Bioscience, A C Meyers Vænge 15, DK 2450 Copenhagen SV, Denmark

${ }^{\mathrm{b}}$ Technical University of Denmark, Department of Chemical and Biochemical Engineering, Søltofts Plads Bldg 228, 2800 Kgs. Lyngby, Denmark

*Corresponding author: e-mail: ivsk@kt.dtu.dk \& ioannis_sk@yahoo.co.uk, tel: +4545252729.
\end{abstract}

The economic feasibility of biochemical conversion of wheat straw to butyric acid was studied in this work. Basic process steps included physicochemical pretreatment, enzymatic hydrolysis and saccharification, fermentation with in-situ acids separation by electrodialysis and product purification. Two scenarios (S1 and S2) were examined assuming a plant with an annual capacity of 10,000 tonnes of product installed in India (due to significantly lower feedstock prices). S1 resulted in a product of $89 \%$ butyric acid mixed with acetic acid and S2 produced butyric acid of 99\% purity. Unit production cost was estimated at 2.75 and 3.31 \$ per kg product for S1 and S2 respectively. The main part of production cost was attributed to steam for the purification step and electricity for the in-situ acids separation. This unit production cost combined with an estimated butyric acid selling price (year 2014) at 3.50 and 3.95 \$ per kg product (for S1 and S2 respectively) and a plant capacity of 10,000 tonnes indicated an internal rate of return of $14.92 \%$ and $12.42 \%$ and payback time of 4.28 and 4.70 years for S1 and S2 respectively. Sensitivity analysis showed that under the assumptions of the present study the optimum plant capacity would lie between 10,000 and 15,000 tonnes of product per year.

Key words: Economic analysis, Wheat straw, Butyric acid, Fermentation, C. tyrobutyricum, Electrodialysis

\title{
1. Introduction
}


1 Butyric acid is a four carbon fatty acid, which is commonly found in milk and milk products

2 such as butter and has diverse applications in food and feed, chemical and pharmaceutical

3 industries (Dwidar et al., 2012). In the chemical industry, the primary application of butyric

4 acid is plastic production (e.g. cellulose-acetate-butyrate) (Cao et al., 2011). Previous research

5 has also shown that butyric acid can be converted to butanol in a two steps fermentation

6 process where sugars are converted to butyric acid in the first step by C. tyrobutyricum and in

7 the second (solventogenic) step, butyric acid is converted to butanol by C. acetobutylicum

8 (Ramey, 1998). The current annual production of butyric acid is estimated to be around

950,000 tonnes (Sauer et al., 2008) and it is mainly produced by oxidation of butyraldehyde

10 (obtained from propylene derived from crude oil by oxosynthesis). Currently, the chemical

11 synthesis of butyric acid is preferred mainly because of its lower production cost and the

12 availability of the starting materials (Dwidar et al., 2012). Due to the increasing petroleum

13 prices (in the long term), the concerns about greenhouse gas emission and global warming and

14 the customers' preferences, butyric acid production from renewable resources is receiving

15 growing interest from the scientific community and the industry (Zhang et al., 2009; Zigova

16 and Sturdik, 2000). However, biological production of butyric acid (e.g. from lignocellulosic

17 biomasses) is relatively costly (Dwidar et al., 2012) and petroleum based production cannot

18 be economically outcompeted by the renewable alternatives so far.

Wheat straw is the most abundant agricultural biomass in the world after rice straw (Kim and Dale, 2004) with, approximately, 600 million tonnes of wheat straw produced

21 globally in 2009 (estimation based on FAO grain production data) (Bakker et al., 2013).

22 Agricultural biomass is extensively exploited for production of power and biofuels.

23 Particularly, in India, agricultural residues (e.g. rice husk, small wood chips, rice husks,

24 cotton stalks, and other agro-residues) are used for grid power generation but the major 
1 portion of agricultural biomass ( e.g straw) is currently left in the fields (Mangaraj and

2 Kulkarni, 2011). However, recent actions encouraged by the governmental policy supporting

3 a low-carbon growth path increased potential exploitation of agricultural biomass (Purohit and

4 Fischer, 2014).

Typical process for biological production of butyric acid from lignocellulosic

6 biomasses such as wheat straw comprises pre-treatment, saccharification, fermentation, extraction and purification. Pre-treatment and enzymatic hydrolysis (saccharification), in general, is similar to 2G ethanol production process (Kazi et al., 2010) with weak acid

9 hydrolysis being one of the most common pretreatment methods also for fermentative butyric 10 acid production (Jha et al., 2014). Fermentation and acids extraction processes have been 11 discussed in several review articles where different in-situ extraction strategies including 12 solvent extraction and electrodialysis were suggested (Dwidar et al., 2012; Zhang et al., 13 2009; Zigova and Sturdik, 2000). Typical solvent extraction methods tested so far include 14 physical extraction, reactive extraction or pertraction using different solvents such as decanol, 15 and alamine 336/oleyl-alcohol with the main disadvantage being their inhibitory effect on the 16 fermentation process. Recently, Baroi et al. (2015) reported promising results from a butyric acid production method based on the fermentation of pre-treated and enzymatically hydrolyzed wheat straw (PHWS), which was successfully tested in laboratory as well as in pilot scale. In this method, a single strain (C. tyrobutyricum, which cannot hydrolyse cellulose or hemicellulose) fermentation process was applied in combination with in-situ acids

21 separation by Reverse Electro Enhanced Dialysis (REED). This resulted at a high butyric acid 22 productivity, yield and selectivity $\left(1.30 \mathrm{~g} \mathrm{~L}^{-1} \mathrm{~h}^{-1}, 0.45 \mathrm{~g} \mathrm{~g}^{-1}\right.$ sugar, and $0.88 \mathrm{~g} \mathrm{~g}^{-1}$ acids respectively) which was accompanied by significantly smaller (but not negligible) acetic acid production. One possibility to eliminate acetic acid in the fermentation step is using a co- 
1 culture of symbiotic microbial species (methanogens), which are able to convert acetic acid

2 and hydrogen (released by butyric acid producing bacteria) to methane but are not able to

3 consume butyric acid and have similar growth requirements with C. tyrobutyricum. This

4 microbial symbiotic relationship is very common and naturally occurs in anaerobic digestion

5 processes (Batstone et al., 2002). Metahnogens such as Methanosarcina sp andMethanosaeta

6 sp. can catabolize $\mathrm{H}_{2}-\mathrm{CO}_{2}$ and acetic acid, respectively (Stams et al., 2003). It is expected that

7 a co-culture of $C$. tyrobutyricum with methanogens will obviously have the advantage of

8 resulting in a fermentation broth containing only butyric acid and (practically) no acetic acid

9 with additional production of methane (which could be used as fuel for the process). On the

10 other hand, the fermentation step will have to be designed for a longer hydraulic retention

11 time in order to avoid washing out of the methanogens which grow slower than $C$.

12 tyrobutyricum(Khanal, 2008).

To our knowledge, the above mentioned butyric acid efficiency is the highest

14 observed so far in suspended growth fermentation systems and therefore, it is worthy to

15 further examine possibilities for upscaling and commercial exploitation. Techno-economic

16 analysis is a fundamental tool for studying the feasibility of new processes and estimating

17 their economic viability and performance. A representative software package which is

18 commercially available and can be used for simulation and techno-economic analysis of

19 processes is SuperPro Designer ${ }^{\circledR}$. SuperPro Designer ${ }^{\circledR}$ has among others been used for the

20 techno-economic analysis of bioethanol production (Kazi et al., 2010; Wooley et al., 2002),

21 bio-diesel production (Marchetti et al., 2008) and biopharmaceutical process optimization

22 (Petrides et al., 2014) by estimating mass and energy balances as well as economic

23 parameters. Furthermore, SuperPro Designer ${ }^{\circledR}$ can provide the distribution of cost over

24 different process sections and perform cash flow analysis. 
In the present study, a complete plant is envisaged where wheat straw is pretreated, enzymatically hydrolyzed and fermented to butyric acid, which is subsequently separated by applying the process developed by Baroi et al. (2015). The plant, which is assumed to have a production capacity of around 10,000 tonnes purified acids as main product

5 (MP) from wheat straw, is analyzed and simulated by SuperPro Designer ${ }^{\circledR}$, technoeconomic

6 analysis is performed and its economic feasibility is evaluated.

\section{Methods}

\section{$9 \quad 2.1$ Description of the process model}

10 The process model includes five major process steps: feedstock handling, pretreatment,

11 saccharification, fermentation and extraction and purification (see figure 1). The detailed 12 process model, developed by using SuperPro Designer ${ }^{\circledR}$ V9.0, is shown in figure 2. In 13 addition to the five sections, the model includes heat and power generation units where by14 products such as solids and biogas are used for steam and power generation. Feedstock

15 handling includes size reduction, which in combination with pretreatment facilitates the 16 disintegration of the lignocellulosic structure of the biomass and thus increases the release of sugar monomers in the saccharification step. The liquid fraction of the latter step is then used for butyric acid fermentation. Organic acids produced in the fermentation step are extracted by distillation in the final purification step.

\section{Figure 1 here}

In most of the single strain fermentation processes developed so far for butyric acid

22 production acetic acid is a side product even after genetic modification (Zhu et al., 2005).

23 Acetic acid is also produced during the pretreatment. Butyric acid purification technologies

24 after extraction are not yet fully developed and often butyric acid is produced as a mixture 
1 (Zigova and Ernest, S, Vandak D, 1999). Acetic acid (boiling point $117.95{ }^{\circ} \mathrm{C}$ ) has an almost

2 similar pKa value as butyric acid (boiling point $164.85{ }^{\circ} \mathrm{C}$ ) and both acids form azeotropic

3 mixtures with water making the purification energy demanding. Hence, two scenarios (S1 and

4 S2) were investigated in this study. S1 is based on the fermentation process developed by

5 Baroi et al. (2015) where a mixture of butyric acid with acetic acid is the main product (MP).

6 S2 is based on the same bacterium used in S1 (C. tyrobutyricum) in coculture with

7 methanogens, which are able to convert acetic acid to methane and thus butyric acid is the

8 MP. Each of the scenarios is modelled in SuperPro Designer where materials and energy

9 balances are developed and then used for the economic evaluation of the processes.

$10 \quad$ Figure 2 here

\subsubsection{Feed stock}

13 Composition, availability and thus prices of wheat straw can vary significantly depending on

14 the climate, soil and harvesting time as well as local market conditions (Molinuevo-Salces et 15 al., 2013). As a result, unit production costs can be affected by these parameters when wheat 16 straw is used as feedstock. In 2009-2010, wheat and rice straw production in India reached 17186 million tonnes and 75\% of this was either burnt or wasted (Mangaraj and Kulkarni, 18 2011). Furthermore, prices of wheat straw in India (0.0125 \$/kg (Mangaraj and Kulkarni, 19 2011)) are considerably lower than in Denmark and Sweden (0.0724 \$/kg (Statistik, 2014) 20 and 0.108 \$/kg (Horváth et al., 2013)) Due to large availability and very low prices of straw it

21 is assumed that the plant for butyric acid production from wheat straw considered in the 22 present study will be located in India. Hence, this study considers India as a potential ground 23 for this process. 
Major constituents of wheat straw are cellulose, hemicellulose and lignin as shown in table 1 . Furthermore, wheat straw contains silica as $13 \%$ to $18 \%$ of ash content

3 (Antongiovanni and Sargentini, 1991; Halvarsson et al., 2010) and 8 to 14\% water (Bauer et

4 al., 2009; Larsen et al., 2012) . The chemical composition of wheat straw used in this study

5 was assumed to be cellulose $39.7 \%$, hemicellulose $23.9 \%$, lignin $20.5 \%$ and ash $5.7 \%$ as

6 averages of the respective values presented in table 1.

Table 1 here

\subsubsection{Feedstock handling and pre-treatment}

10 Feedstock handling includes wheat straw washing and size reduction. Fresh water

11 requirement in this process is assumed to be minimal since water generated in downstream 12 purification steps is used in the washing step. Washed straw is passed through a grinder for 13 size reduction down to $2-3 \mathrm{~mm}$ increasing the surface area, which facilitates the subsequent 14 physicochemical pre-treatment step (Njoku et al., 2012). Storage cost is not taken into account

15 for the estimation of unit production cost in this study. The primary objective of the pretreatment is to make the carbohydrates, imbedded in lignocellulosic biomass, accessible for enzymatic hydrolysis (saccharification) (Galbe and Zacchi, 2002; Taherzadeh and Karimi, 2008). In the process considered in the present study,

19 washed and grinded straw is transferred to the pretreatment reactor where it undergoes wet 20 explosion (reactions outlined in table 2) followed by pressure release and temperature drop to

211 bar and $32{ }^{\circ} \mathrm{C}$ respectively in a flash tank. Wet explosion is carried out at $150{ }^{\circ} \mathrm{C}$, retention 22 time of $15 \mathrm{~min}, \mathrm{H}_{2} \mathrm{SO}_{4}$ concentration of $0.3 \%$ (w/w), total solids (TS) content of $12-13 \%$ and 23 a pressure of 6 bar (Biswas et al., 2013; Njoku et al., 2012). Heat released in this step is 24 recycled to preheat the biomass feeding stream to the pretreatment reactor. The pretreated 
1 straw is transferred from the flash tank to the saccharification step. For the purpose of the

2 present study and in order to avoid the modelling of very complex commercial scale

3 pretreatment reactor design, for which there is not enough information available (Kumar and

4 Murthy, 2011), the pretreatment step is assumed to be one piece of equipment shown in figure

52 (pretreatment reactor grouping together a series of equipment such as screw conveyors,

6 tanks, reactor, flash tank etc.)

$7 \quad$ Table 2 here

\section{$9 \quad$ 2.1.3 Saccharification}

10 The slurry, produced after the pretreatment, has a very low $\mathrm{pH}(<5.0)$ and therefore, prior to 11 enzymatic hydrolysis, $\mathrm{pH}$ is adjusted to 5 by adding $\mathrm{NaOH}$. Enzyme complex dose (Cellic 12 CTec2), reaction temperature, and residence time are $50 \mathrm{~g} / \mathrm{kg}$ cellulose, $30^{\circ} \mathrm{C}$ and 24 hours

13 respectively (Öhrman et al., 2013). Reactions and conversion efficiency used in

14 saccharification modeling are shown in table 2. After saccharification, the remaining solids

15 are separated by a belt-filter as suggested by Wooley et al. (2002). During this filtration step,

16 water is used for washing purposes at so small quantities that it may be assumed as negligible

17 without introducing significant error in the overall process modelling and calculations. The 18 separated solid fraction, usually called 'cake', is characterized by a moisture content of 50\%

19 and is used for heat and power generation. The remaining liquid stream is utilized as the 20 substrate for the following fermentation step.

21

\section{2.1.4 Fermentation coupled with extraction}

23 Prior to fermentation, the liquid is neutralized with potassium hydroxide, and urea and

$24 \mathrm{~K}_{2} \mathrm{HPO}_{4}$ are added at a concentration of $4.5 \mathrm{~g} / \mathrm{L}$ and $0.64 \mathrm{~g} / \mathrm{L}$ respectively. The mixture is then 
1 sterilized at a temperature of $140{ }^{\circ} \mathrm{C}$ and pumped into the fermentation tank. For both scenarios (S1 and S2) examined in this study the fermentation is carried out at a temperature of $37{ }^{\circ} \mathrm{C}$ and pH 7 following the fermentation stoichiometry and conversion efficiencies presented in table 2. The hydraulic retention time (HRT) is not assumed the same in the two scenarios. As demonstrated by Baroi et al., (2015), recommended HRT for scenario S1 is 1.28 d. However, the maximum specific growth rate for methanogens is between 0.25 and $0.5 \mathrm{~d}^{-1}$ (Gavala et al., 2003) which corresponds to a minimum HRT between 2 and $4 \mathrm{~d}$ for the methanogens to grow fast enough and not being washed out. Thus the HRT for scenario S2 is

9 assumed to be $2 \mathrm{~d}$. C. tyrobutyricum, which is assumed in this study, has previously been well 10 adapted to the fermentation medium (wheat straw hydrolysate) (Baroi et al., 2015; Baroi et 11 al., 2015a) and therefore, is not expected to be affected by any inhibition. On the other hand, methanogens may be inhibited by compounds in wheat straw hydrolysate(Shanmugam et al., 2014). Based on literature data, it is assumed here that this inhibition effect is not severe and also that adaptation of the methanogens will take place and thus the longer hydraulic retention time used in S2 will be sufficient to maintaining a healthy methanogens population in the fermentation system (Rivard and Grohmann, 1991). For both S1 and S2 scenarios the fermentor is connected with a membrane system for in-situ separation of butyric acid. Specifically, the fermentation broth flows through a REED anion-exchange membrane unit where organic acid anions (e.g. $\left.\mathrm{CH}_{3}\left(\mathrm{CH}_{2}\right) \mathrm{COO}^{-}\right)$are removed from the broth facilitated by an electric field and replaced by $\mathrm{OH}^{-}$coming from a $\mathrm{NaOH}$

21 solution flowing at the opposite side of the membrane. The organic acid anions are then 22 combined with the remaining $\mathrm{Na}^{+}$and the formed salt solution is passed through an EDBM 23 (electrodialysis with bipolar membrane) unit which regenerates the $\mathrm{NaOH}$ and releases a 24 water solution of the organic acids as demonstrated by (Garde, 2002; Wang et al., 2013). In 
1 this process, there is a loss of a small part of $\mathrm{NaOH}$, which is replenished by an external

2 addition of a $\mathrm{NaOH}$ solution. Butyric acid and acetic acid recovery efficiencies for the REED

3 unit are 90\% and 91\% respectively as reported by Baroi et al. (2015). Organic acids recovery

4 efficiency of EDBM is assumed to be $100 \%$ which is similar to that used by Garde (2002) for

5 lactic acid production. Based on estimations made by Jurag Separation A/S, the providers of

6 REED/EDBM technology, the butyric acid content of the acid solution generated by the

7 EDBM unit was expected to be around 5.5\%. In the present study, the REED/EDBM units are

8 modeled as one unit for simplification purposes. Detailed operational parameters and

9 technical characteristics of REED/EDBM are presented in table 3. Finally, the effluent from

10 the fermentation tank (from which organic acids have been removed and recovered) is

11 assumed to be wastewater that requires proper treatment and disposal.

Table 3 here

\subsubsection{Purification}

15 The purification steps include storage, extraction and distillation units. 1-octanol (as a

16 representative model solvent) was selected for the extraction of organic acids from the water

17 phase coming from the REED/EDBM unit. The partition co-efficient (PC) of butyric acid in

18 octanol was 6.17 and the PC of acetic acid was 0.68 . The solubility or entrainment of water in

19 octanol or octanol in water was assumed $0.01 \mathrm{~g} / \mathrm{L}$. After extraction, the octanol phase that

20 contains the organic acids is distilled. The organic acids (butyric and acetic acids for S1 or

21 only butyric acid for S2), which are more volatile than octanol are collected from the top of

22 the distillation column as the main product while octanol leaves from the bottom of the

23 distillation vat and is recycled back to the extraction unit after replenishment of the octanol

24 losses. Detailed operational parameters and technical characteristics of extraction and 
1 distillation units are presented in table 3. The distillation processes were modelled in

2 SuperPro Designer® using a semi-empirical shortcut method (Fenske-Underwood-Gilliland).

3 The distillation column is operated at a reflux ratio of 41 and 48 for S1 and S2 respectively.

4 Heat recovered from the distillation effluent streams is used for pre-heating the feed stream.

5 The water phase from the bottom of the extraction unit is used as washing water in the straw

6 washing unit and finally ends up as wastewater that requires proper treatment and disposal.

$8 \quad$ 2.1.6 Combined heat and power (CHP) generation

9 The filter cake, which is produced during belt filtration of hydrolyzed straw as well as the

10 biogas from the fermentation unit are combusted for heat and power production where well

11 water is used for steam generation. It is assumed that the steam and electricity produced in

12 this step are fully consumed by the modelled enterprise to cover energy needs of the rest of

13 the process steps. Detail operating parameters for CHP are presented in table 3, There is a

14 possibility to tune parameter in SuperproDesigner ${ }^{\circledR}$ to get different pressure steam in order to

15 satisfy the needs of the production process. However, default values were chosen for steam

16 generator.

2.2 Economic analysis

19 The economic evaluation of butyric acid production from wheat straw studied in the present

20 work involved the estimation of capital cost, variable and fixed operating costs as well as

21 profitability. SuperPro Designer ${ }^{\circledR}$ was used in order to model and simulate the production

22 process. The calculated material and energy balances were then used for equipment sizing and

23 cost estimation. The purchase costs for some of the equipment (such as belt filtration,

24 sterilization unit, extraction, distillation unit, steam generation unit, heat exchangers and 
1 coolers) were obtained from SuperPro Designer ${ }^{\circledR}$ existing databases combined with the build-

2 in scaling law (equation 1) while for others (such as washing table, shredder, pretreatment

3 vessel, flush tank, enzymatic hydrolysis, fermentation reactor, storage tanks, REED and

4 EDBM) the purchase costs calculations were based on the simulated equipment sizes and the

5 application of scaling law with specific equipment index taken from previous reports (Aden et

$6 \quad$ al., 2002; Garde, 2002).

8 New Cost $=$ Original Cost $\left(\frac{\text { New Size }}{\text { Orizinal Size }}\right)^{n}$

9 Where $n=$ specific equipment index

11 Additionally, SuperPro Designer ${ }^{\circledR}$ accounted for the cost of secondary equipment, which was 12 not listed for model simplification purposes. The purchase cost of this unlisted equipment was 13 estimated to be $20 \%$ of the purchase cost of listed equipment. Finally and as recommended by

14 SuperPro Designer ${ }^{\circledR}$, maintenance cost was assumed to be $10 \%$ of the total equipment

15 purchase cost. Equipment, raw materials and labor purchase costs which are subject to

16 changes with time due to inflation and other parameters influencing market conditions were

17 estimated by equation 2, where specific indexes are used to estimate the purchase cost for the

18 desired year (Cost2) when the cost is known for a previous year (Cost 1):

19

$20 \operatorname{Cost} 2=\operatorname{Cost} 1 \frac{\text { Index }_{2}}{\text { Index }_{1}}$

The necessary parameters for the estimation of the total capital investment cost and operating

23 cost of the process were obtained from literature (Humbird et al., 2011; Ou et al., 2014). Thus,

24 the project life and the depreciation period were taken as 20 and 10 years respectively while 
1 the salvage value, the construction and start-up period and the inflation rate were $5 \%$, 30 months, 6 months and 4\% respectively.

\subsubsection{Raw materials, consumables, utilities, labor and waste disposal costs}

5 The prices of raw materials used in the present process modeling and economic evaluation are

6 shown in table 4 . Where necessary, the prices have been adjusted by indexing them to year

72014 as suggested by Aden et al. (Aden et al., 2002). The price of wheat straw used as

8 feedstock in this study was $0.0125 \$ / k g$ (see also section 2.1.1 Feedstock). Octanol price

9 varied from $1.65-1.83 \$ / \mathrm{kg}$ but an average value of $1.7 \$ / \mathrm{kg}$ was used in this study. Also, it

10 was assumed that the enzyme prices would remain stable during the years included in the

11 evaluation even though one can expect lowering prices due to future technological

12 development. Prices of consumables such as membranes used for REED (198 \$/m²) and

13 EDBM (1567 \$/m²) were taken from Garde (2002) and adjusted for the year 2014 using

14 equation 2. Purchase costs of utilities such as water (0.203 \$/tonne), electricity (0.07 \$/kWh)

15 and steam $\left(115^{\circ} \mathrm{C}, 60.95\right.$ \$/tonne) as well as labor price (basic $\left.2.5 \$ / \mathrm{h}\right)$ are taken from

16 literature (Burkley, 2014; Sikder et al., 2012) and, where necessary, they were adjusted for the

17 year 2014. It is remarkable though, that steam price in India seemed several times higher

18 compared to what has been reported in other similar studies for ethanol production (17.08

19 \$/tonne (year 2006 price) (Kwiatkowski et al., 2006)) or biogas production (4.05 \$/tonne (

20 year 2013 price) (Shafiei et al., 2013)). The above are the buy-in prices of energy utilities, if

21 the CHP does not satisfy demand.

The cost for wastewater treatment and disposal can vary significantly depending

23 on its organic load (BOD or COD content). Harrison et al. (2013) reported a disposal fee of

$240.2 \$ / \mathrm{m}^{3}$ to $0.5 \$ / \mathrm{m}^{3}$ for waste water having a BOD content less than $1000 \mathrm{mg} / \mathrm{L}$ which was 
1 the expected organic load of the effluent from wheat straw wash unit. However, the wastewater mixture generated during the present butyric acid production process, that is the

3 fermentation effluent mixed with the effluent from straw wash unit, was expected to have

4 significantly higher organic load. Buyukkamaci and Koken, (2010) estimated a cost of 0.7-

$5 \quad 2.35 \$ / \mathrm{m}^{3}$ for the treatment of high strength (10 g COD/L and $5 \mathrm{~g} / \mathrm{L}$ suspended solids) paper

6 and pulp industry wastewater. Garde (2002) used a cost of $2.36 \$ / \mathrm{m}^{3}$ for the treatment of

7 wastewater from a fermentative lactic acid production process. The cost for wastewater (both

8 fermentation effluent and washing water) treatment assumed in this study was $2 \$ / \mathrm{m}^{3}$. Finally,

9 the cost for the disposal of the ash generated in the heat and power section was assumed to be 10 at $0.0041 \$ / \mathrm{kg}$ (Wooley et al., 2002). The costs of the waste/wastewater treatment and

11 disposal are not necessarily representative of those in India. These costs are bound to vary 12 considerably across municipalities, and even more so across continents. However, these costs

13 are usually a very small portion of the total operating cost and it is assumed in the present 14 study that they cannot influence significantly the economics of the examined production 15 process. This assumption is confirmed from the results of the present study presented below 16 in section 3.2. Furthermore, the used costs are representative of North Europe and North 17 America which (due to very strict environmental regulations) present the highest costs compared to other geographical areas and thus the economic evaluation results of the present

19 study cannot be influenced negatively by locating the production unit in India.

\section{Table 4 here}

\subsubsection{Product price}

23 Current market price of butyric acid was not possible to be recovered from public databases.

24 However, butyric acid price can be estimated from the price of n-butyraldehyde, which is the 
1 raw material used during the chemical synthesis of butyric acid. Zidwick et. al. ( 2013)

2 reported a butyric acid price of $1.5 \$ / \mathrm{kg}$ in year 1982 based on the market price of $\mathrm{n}$ -

3 butyraldehyde. Since then, there has been a considerable increase of oil price, which has

4 resulted to significant increases of butyric acid price reported by producers such as

5 EASTMAN (www.eastman.com) or OXEA (www.oxea-chemicals.com). Recently, OXEA

6 has reported a list price of n-butyraldehyde at 3.95 \$/kg (OXEA, 2014) and thus list price of

7 butyric acid can be be $4.78 \$ / \mathrm{kg}$ (production cost factor of 1.21 was calculated based on the

8 data reported by Zidwick et al. (2013)). However, due to the uncertainties with the above

9 price estimations it has been chosen a minimum price for butyric acid of $3.95 \$ / \mathrm{kg}$ being the

10 same with that of n-butyraldehyde. Thus the economic evaluation was performed on a worst

11 case scenario where the price of butyric acid produced through chemical synthesis will be so

12 low as this of n-butyraldehyde. The purity of the commercially available butyric acid varies

13 from 99 to $99.5 \%$. In order to perform cash flow analysis in this study the price of butyric acid

14 (purity $>99 \%$ ) was assumed to be $3.95 \$ / \mathrm{kg}$. The main product resulting from scenario S1 is a

15 mixture of butyric acid and acetic acid. Butyric acid content in this mixture is $89 \%$. Based on

16 a $89 \%$ purity of butyric acid, the price of the product from S1 was assumed to be $3.50 \$ / \mathrm{kg}$,

17 calculated proportionally from the price used for the product with $99 \%$ purity. The product

18 from S2 was assumed to be pure (99\%) butyric acid.

\subsection{Parameters for Sensitivity analysis}

21 Depending on local conditions and their yearly variation, such as climate, yield of crops,

22 and feedstock availability versus demand, the price of feedstock (wheat straw) may have a

23 large variation and thus affect substantially the unit production cost. In order to demonstrate

24 the effect of wheat straw price as well as that of plant size (capacity) and selling price of main 
1 product on the profitability of the whole enterprise, a sensitivity analysis was performed

2 (single parameter at a time) by using SuperPro Designer ${ }^{\circledR}$ Component Object Model (COM)

3 interface in combination with Microsoft Excel ${ }^{\circledR}$ interface.

3. Results and Discussion:

$6 \quad 3.1$ Economic summary of the scenario S1 and S2

7 The economic results for plant product capacity of 10,000 tonnes per year after simulation of

8 both S1 and S2 scenarios are presented in tables 5 and 6. Based on a market price (year 2014)

9 estimation for butyric acid at $3.95 \$ / k g$ (purity 99\%) both scenarios showed encouraging

10 results. Unit production cost was estimated at $2.75 \$ / \mathrm{kg}$ product and 3.31 \$/kg product for S1

11 and S2 respectively. For the plant capacity examined in this study (10,000 tonnes of product 12 per year) this reveals a very efficient investment with Internal Rate of Return (after tax) of

$13 \quad 14.92 \%$ and $12.42 \%$ and payback time of 4.28 and 4.7 years for S1 and S2 respectively.

14 Total Lang factors (Peters and Timmerhaus, 1991) of 5.07 and 5.10 were used for S1 and

15 S2 respectively to estimate total capital investment based on equipment purchase cost. This

16 estimation resulted in a total capital investment for scenarios S1 and S2 of 47.71 and 53.68

17 million \$ respectively. Due to the conversion of acetic acid to methane in S2, S1 results in

18 higher amount of MP produced per unit amount of straw consumed and thus S1 is required to

19 convert a smaller amount of wheat straw(140 tonnes compared to 156 tonnes per day) in order

20 to produce 10,000 tonnes of MP per year. Consequently, the equipment size in S1 is slightly

21 smaller than in S2 and accordingly the estimated capital investment for S1 is smaller than for

22 S2. In order to test how realistic are the above estimated capital investments a comparison

23 with the results from a similar study by Humbird et al. (2011) was made. This comparison

24 revealed that for the same raw material capacity used by Humbird et al. (i.e. 2,000 tonnes of 
raw material per day) S1 and S2 would require a total capital investment of 410,652,000 \$ and

$2426,090,000$ respectively which is almost the same with the 422,500,000 \$ estimated by

3 Humbird et al. Operating cost was slightly higher for S2 (33.12 million \$) compared with S1

4 (27.52 million \$) scenario which (after taking into consideration that butyric acid purity for

$5 \quad$ S1 and S2 was $89 \%$ and $99 \%$ respectively) resulted in an increased (20\%) unit production

6 cost for scenario S2. A small amount of credit was obtained due to electricity and steam

7 generation in the heat and power section (figure 3a) and this has resulted to a $16 \%$ reduction

8 of the unit production cost.

Figure 3 here

\section{Table 5 here}

\section{Table 6 here}

Direct Fixed Capital Cost and its breakdown to different cost categories are

13 shown in table 6. Estimated Direct Fixed Capital Cost for S1 and S2 is 40.32 and 45.07

14 million \$ respectively. The highest equipment purchase cost was attributed to the pretreatment

15 section (26\%) followed by fermentation and extraction section (22\%) and purification section

16 (21\%). Detailed equipment costs and respective size or capacity of each unit are presented in

17 appendix A.

\subsection{Operating cost distribution for scenarios S1 and S2}

20 The different operating cost categories for scenarios S1 and S2 are shown in table 7. Utility

21 costs are the highest (52.7\% and $55.0 \%$ of the total operating cost for S1 and S2 respectively)

22 followed by facility dependent costs (28.4\% and $26.36 \%)$ and raw material costs (8.1\% and

23 7.6\%). Facility dependent costs include maintenance, deprecation and miscellaneous costs. 
Operating costs distributed among the six sections of the process are shown in figure 3b.

2 For both S1 and S2 scenarios, purification section was the most costly one accounting for $\sim 50$

$3 \%$ of the total operating cost. Fermentation accounted for $\sim 26 \%$, pretreatment $\sim 11 \%$,

4 saccharification $\sim 5.5 \%$ and feed stock handling 4\% for both S1 and S2.

The operating costs of the purification section was estimated at 13.62 and 17.12 million

6 \$ for S1 and S2 respectively. This means that the purification section accounted for more than $80 \%$ of the total utility costs followed by fermentation and separation (15\%), heat and power section ( 2\%) and pretreatment ( 1\%). As mentioned above, steam is relatively expensive in

9 India and thus, steam alone contributed to $34.2 \%$ and $35.8 \%$ of the total operating cost of S1

10 and S2 respectively (table 7). A large amount of steam (154,419 tonnes for S1 and 194,274

11 tonnes for S2) and cooling water (12.83 million tonnes for S1 and 16.16 million tonnes for

12 S2) were used by the process. However, $46.7 \%$ (S1) and $44.4 \%$ (S2) of the total steam

13 demand could in principle be covered by the CHP unit (see figure 3a).

The operating cost of fermentation and separation section was estimated at 7.5 and 8.5

15 million \$ (for S1 and S2 respectively), of which, utility costs were approximately 33\%. A

16 significant amount of electricity was required for REED and EDBM units. Total electricity

17 purchase cost for the entire plant was estimated at 2.4 and 2.8 million $\$$. Almost $95 \%$ of the

18 electricity consumption of the entire plant was used in fermentation and separation section.

19 Total electricity consumption by S1 and S2 was 34.4 and 39.4 GWh/year respectively.

20 However, a very small amount of electricity ( 0.35 and $0.38 \%$ of the total plant consumption

21 for scenario S1 and S2) is generated by the CHP section.

22 The cost of replacement of REED and EDBM membranes corresponded to

23 approximately $20 \%$ of the operating cost of fermentation and separation section. Among the

24 different raw materials used, urea (as nitrogen source for microbes) was the most costly and 
corresponded to almost $2.5 \%$ of the total operating costs. Costs for wheat straw, $\mathrm{NaOH}$ and enzymes were significant but not as high. The total amount of wheat straw necessary for the production of 10,000 tonnes MP from S1 and S2 was 44,060 and 49,820 tonnes respectively.

\section{Table 7 here}

(1)

\subsection{Sensitivity analysis}

Sensitivity analysis was performed to determine the potential effect of wheat straw prices on the unit production cost for scenarios S1 and S2 and the results are shown in figure 4a. A hypothetical increase of $1000 \%$ in the purchase price of feedstock may cause an $80 \%$ increase in production cost for S1 and S2, indicating that in general feedstock price has a minor effect . This result could be explained by the fact that, in the specific case handled in the present study, wheat straw purchase cost $(0.01 \$ / \mathrm{kg})$ contributed with a relatively small percentage to the total operating cost. Apparently, this cost increment may not be significant under the assumptions of the present study but it is likely that this picture will change in the future due to lower availability of wheat straw as a result of, for example, installation of a number of wheat straw based production plants or low crops efficiency, due to climate change.

Furthermore, wheat straw prices may have had a more significant impact on the unit production cost if the necessary heat and power were produced through the combustion of wheat straw together with the produced biogas and solid cake. However and according to our knowledge, similar phenomena have not been observed for another biomass type and, thus, this alternative was not taken into consideration during the present sensitivity analysis.

\section{Figure 4 here}

The effect of plant size (capacity) on the unit production cost as well as revenue, net profit, return of investment (ROI) and internal rate of return (IRR) for S1 and S2 may be seen 
1 in figures 4b and 5. The unit production costs decrease nonlinearly with increasing plant size.

2 The unit production cost increase sharply with plant sizes less than 10,000 tonnes MP/year

3 while it is not affected significantly (the curve is almost flat) for plant sizes higher than

4 15,000 tonnes MP/year implying that a plant with a production capacity smaller than 10,000

5 tonnes MP per year would most probably be a very weak choice. This is clearly supported

6 also from the investment performance indexes (ROI and IRR) presented in figure 5 where

7 both ROI and IRR decrease sharply for plant sizes smaller than 10,000 tonnes MP /year for

8 S1 as well as for S2. While profit keeps increasing linearly with plant size, ROI and IRR

9 follow a rather different behavior where an increase of plant size above 10,000-15,000 tonnes

$10 \mathrm{MP} /$ year results to a disproportional smaller increase of these indexes. Given the fact that the

11 present economic evaluation has not taken into consideration the possible limitations with

12 wheat straw availability for large scale plants which could result in deterioration of these

13 indexes, one could conclude that a reasonable plant size would lie between 10,000 and 15,000

14 tonnes MP/year with an IRR (after tax) around 16\%.

Figure 5 here

Payback time decreases and IRR increases when the selling price of the product increases. The payback time for a plant with a capacity of 10,000 tonnes MP per year with selling price of 3.50 and $3.95 \$ / \mathrm{kg}$ MP was estimated at 4.28 and 4.70 years for scenarios S1 and S2 respectively (see figure 6). When the selling price of MP was less than 2.8 \$/kg for S1 and 3.2 \$/kg for S2, IRR became zero and the investment could not be paid back. Thus one can conclude that the above prices are the minimum MP celling prices for a plant with a capacity of 10,000 tonnes MP per year.

\section{Figure 6 here}


3.3 Alternative approach for heat and power production

As it is evident from the figures in table 7, utility cost for both scenarios S1 and S2 became

3 quite high mainly due to the high purchase cost of steam. Therefore, instead of purchasing

4 steam, one could generate the necessary process steam in the plant's heat and power section

5 where wheat straw or rice straw or both, depending on the availability, could be combusted

6 for steam generation. As it can be seen in table 8, this would of course result in an increased raw materials purchase cost (an additional 69100 tonnes/yr and 84800 tonnes /yr wheat straw

8 would be necessary for S1 and S2 respectively) and cost of heat and power section but it

9 would also considerably decrease the utility cost. Thus the total operating cost would be lower

10 and finally it would have been possible to operate the plant at the same capacity but at a lower

11 unit production cost. For example, if wheat straw alone was used for the generation of the

12 process steam required for the production of 10,000 tonnes MP per year, operating cost could

13 be reduced by 33 and $35 \%$ and, similarly, unit production cost could be reduced to 1.84 and

$142.16 \$ / \mathrm{kg}$ MP for S1 and S2 respectively (table 8). It needs to be mentioned here that, in the

15 present study, the butyric acid is meant as a commodity chemical and not as a fuel and, as

16 such, its production will always demand some external energy supplies. This production can

17 of course be pushed to a more sustainable direction if the external energy (e.g. electricity) can

18 be supplied by renewable sources such as wind or solar energy instead of fossil resources.

Table 8 here

\section{Conclusions}

23 A wheat straw based plant with a butyric acid production capacity of 10,000 tonnes per year

24 through pretreatment, enzymatic hydrolysis, fermentation and in-situ membrane extraction 
1 was envisaged and economically evaluated in the present study. The plant design and economic evaluation was based on processes simulation using SuperPro Designer ${ }^{\circledR}$ V9.0 software. The hypothetical plant was chosen to be located in India where the feedstock purchase cost was found to be very low. Two different scenarios (S1 and S2) of fermentative

5 butyric acid production from wheat straw were developed and evaluated in this work.

6 Scenario S1 resulted in the production of butyric acid (89\% purity) in mixture with acetic acid 7 and scenario S2 resulted in the production of butyric acid of 99\% purity. The higher product 8 purity from scenario S2 was not enough for improving the economy of the process since the 9 utilities demand per unit of processed feedstock remained approximately the same and more 10 feedstock had to be handled in order to result at the same annual production capacity as S1.

11 Feedstock (wheat straw) purchase cost, which was relatively very small, was not found to 12 have any substantial impact on the economic efficiency of the plant. On the contrary, utilities 13 were the most decisive cost parameter mainly due to the consumption of relatively expensive 14 steam in the purification (distillation) section. When the selling price of butyric acid was less 15 than $2.8 \$ / \mathrm{kg}$ for S1 and 3.2 \$/kg for S2, IRR became zero and the investment could not be 16 paid back. Thus, one can conclude that the above prices are the minimum MP selling prices for a plant with a capacity of 10,000 tonnes product per year. An alternative in-house steam production through straw combustion could decrease the unit production cost down to 1.84 and 2.16 \$/kg of product for S1 and S2 respectively. Increasing plant size had a positive effect on revenue and profit but could not significantly increase IRR. Given the fact that the present

21 study has not taken into consideration the possible limitations with wheat straw availability 22 and the resulting increase of feedstock purchase cost for large scale plants, a reasonable plant size would lie between 10,000 and 15,000 tonnes of product per year. 
1 Process flow diagrams for the two scenarios studied (S1 and S2) built on SuperPro Designer ${ }^{\circledR}$

$2 \quad$ V9.0 platform are provided as supplementary material. Binary plots of 1-octanol and butyrate

3 and acetate are presented in the appendix

\section{Acknowledgement}

6 The authors wish to thank the Commission of the European Communities for the financial support of this work under SUPRABIO project (FP7-cooperation).

\section{References}

Aden, A., Ruth, M., Ibsen, K., Jechura, J., Neeves, K., Sheehan, J., Wallace, B., Montague, L., Slayton, A., Lukas, J., 2002. Lignocellulosic Biomass to Ethanol Process Design and 
from pretreated and hydrolysed wheat straw by an adapted Clostridium tyrobutyricum strain. Microb. Biotechnol. 8, 874-882. doi:10.1111/1751-7915.12304

Baroi, G.N., Skiadas, I. V, Westermann, P., Gavala, H.N., 2015b. Continuous fermentation of wheat straw hydrolysate by Clostridium tyrobutyricum with in-situ acids removal. Waste and Biomass Valorization. doi:10.1007/s12649-015-9348-5

Batstone, D., Keller, J., Angelidaki, I., 2002. Anaerobic digestion model no. 1. Scientific and technical report no. 13. IWA Task Group for Mathematical Modelling of Anaerobic Digestion Process.

Bauer, A., Bösch, P., Friedl, A., Amon, T., 2009. Analysis of methane potentials of steamexploded wheat straw and estimation of energy yields of combined ethanol and methane production. J. Biotechnol. 142, 50-5. doi:10.1016/j.jbiotec.2009.01.017

Biswas, R., Uellendahl, H., Ahring, B.K., 2013. Conversion of C6 and C5 sugars in undetoxified wet exploded bagasse hydrolysates using Scheffersomyces (Pichia) stipitis CBS6054. AMB Express 3, 42. doi:10.1186/2191-0855-3-42

Burkley, T., 2014. BRIEFING NOTE- Indian power prices. Institute for energy economics and financial analysis, IEEFA, Australasia.

Buyukkamaci, N., Koken, E., 2010. Economic evaluation of alternative wastewater treatment plant options for pulp and paper industry. Sci. Total Environ. 408, 6070-8. doi:10.1016/j.scitotenv.2010.08.045

Cao, Y., Li, H., Zhang, J., 2011. Homogeneous synthesis and characterization of cellulose acetate butyrate (CAB) in 1-Allyl-3-methylimidazolium chloride (AmimCl) ionic liquid. Ind. Eng. Chem. Res. 50, 7808-7814. doi:10.1021/ie2004362

Dwidar, M., Park, J.-Y., Mitchell, R.J., Sang, B.-I., 2012. The future of butyric acid in industry. ScientificWorldJournal. 2012, 471417. doi:10.1100/2012/471417 
1 Galbe, M., Zacchi, G., 2002. A review of the production of ethanol from softwood. Appl. Microbiol. Biotechnol. 59, 618-28. doi:10.1007/s00253-002-1058-9

Garde, A., 2002. Production of lactic acid from renewable resources using electrodialysis for product recovery. PhD Diss. Technical University of Denmark.

Gavala, H.N., Angelidaki, I., Ahring, B.K., 2003. Kinetics and modeling of anaerobic digestion process. Adv. Biochem. Eng. Biotechnol. 81, 57-93.

Georgieva, T.I., Hou, X., Hilstrøm, T., Ahring, B.K., 2008. Enzymatic hydrolysis and ethanol fermentation of high dry matter wet-exploded wheat straw at low enzyme loading. Appl. Biochem. Biotechnol. 148, 35-44. doi:10.1007/s12010-007-8085-z

Halvarsson, S., Edlund, H., Norgren, M., 2010. WHEAT STRAW AS RAW MATERIAL FOR MANUFACTURE OF STRAW MDF. BioResources 5, 1215-1231.

Hansen, M.A., Hidayat, B.J., Mogensen, K.K., Jeppesen, M.D., Jørgensen, B., Johansen, K.S., Thygesen, L.G., 2013. Enzyme affinity to cell types in wheat straw (Triticum aestivum L.) before and after hydrothermal pretreatment. Biotechnol. Biofuels 6, 54 . doi:10.1186/1754-6834-6-54

Harrison, R., Todd, P., Rudge, S., Petrides, D., 2013. Bioprocess Design and Economics, in: Bioseparations Science and Engineering. pp. 1-83.

Horváth, I., Castillo, M. del P., Berglund Odhner, P., Teghammar, A., Mohseni Kabir, M., Olsson, M., Ascue, J., 2013. Biogas från lignocellulosa Tekno-ekonomisk utvärdering av förbehandling med NMMO.

Humbird, D., Davis, R., Tao, L., Kinchin, C., Hsu, D., Anden, A., 2011. Process Design and Economics for Biochemical Conversion of Lignocellulosic Biomass to Ethanol Process Design and Economics for Biochemical Conversion of Lignocellulosic Biomass to Ethanol. 
1 Jha, A.K., Li, J., Yuan, Y., Baral, N., Ai, B., 2014. A review on bio-butyric acid production and its optimization. Int. J. Agric. Biol. 16, 1019-1024.

Kazi, F.K., Fortman, J. a., Anex, R.P., Hsu, D.D., Aden, A., Dutta, A., Kothandaraman, G., 2010. Techno-economic comparison of process technologies for biochemical ethanol production from corn stover. Fuel 89, S20-S28. doi:10.1016/j.fuel.2010.01.001

Khanal, S.K., 2008. Methanogenic Bacteria, in: Khanal, S.K. (Ed.), Anaerobic Biotechnology for Bioenergy Production: Principles and Applications. Wiley-Blackwell, pp. 35-37.

Kim, S., Dale, B.E., 2004. Global potential bioethanol production from wasted crops and crop residues. Biomass and Bioenergy 26, 361-375. doi:10.1016/j.biombioe.2003.08.002

Kumar, D., Murthy, G.S., 2011. Impact of pretreatment and downstream processing technologies on economics and energy in cellulosic ethanol production. Biotechnol. Biofuels 4, 27. doi:10.1186/1754-6834-4-27

Kwiatkowski, J.R., McAloon, A.J., Taylor, F., Johnston, D.B., 2006. Modeling the process and costs of fuel ethanol production by the corn dry-grind process. Ind. Crops Prod. 23, 288-296. doi:10.1016/j.indcrop.2005.08.004

Larsen, J., Haven, M.Ø., Thirup, L., 2012. Inbicon makes lignocellulosic ethanol a commercial reality. Biomass and Bioenergy 46, 36-45. doi:10.1016/j.biombioe.2012.03.033

Ljunggren, M., Wallberg, O., Zacchi, G., 2011. Techno-economic comparison of a biological hydrogen process and a 2nd generation ethanol process using barley straw as feedstock. Bioresour. Technol. 102, 9524-31. doi:10.1016/j.biortech.2011.06.096

Mangaraj, S., Kulkarni, S., 2011. Field Straw Management-A Techno Economic Perspectives. J. Inst. Eng. 8, 153-159.

Marchetti, J.M., Miguel, V.U., Errazu, a. F., 2008. Techno-economic study of different 
alternatives for biodiesel production. Fuel Process. Technol. 89, 740-748. doi:10.1016/j.fuproc.2008.01.007

Molinuevo-Salces, B., Larsen, S.U., Ahring, B.K., Uellendahl, H., 2013. Biogas production from catch crops: Evaluation of biomass yield and methane potential of catch crops in organic crop rotations. Biomass and Bioenergy 59, 285-292. doi:10.1016/j.biombioe.2013.10.008

Njoku, S.I., Ahring, B.K., Uellendahl, H., 2012. Pretreatment as the crucial step for a cellulosic ethanol biorefinery: testing the efficiency of wet explosion on different types of biomass. Bioresour. Technol. 124, 105-10. doi:10.1016/j.biortech.2012.08.030

Ou, L., Brown, T.R., Thilakaratne, R., Hu, G., Brown, R.C., 2014. Techno-economic analysis of co-located corn grain and corn stover ethanol plants. Biofuels, Bioprod. Biorefining 8, 412-422. doi:10.1002/bbb.1475

OXEA, 2014. Oxea Announces Global Price Increases. News release 49, 1.

Peters, M.S., Timmerhaus, K.D., 1991. Plant Design and Economics for Chemical Engineers, 4th ed. ed. McGraw-Hill, Inc., New York.

Petersen, M.Ø., Larsen, J., Thomsen, M.H., 2009. Optimization of hydrothermal pretreatment of wheat straw for production of bioethanol at low water consumption without addition of chemicals. Biomass and Bioenergy 33, 834-840. doi:10.1016/j.biombioe.2009.01.004

Petrides, D., Carmichael, D., Siletti, C., Koulouris, A., 2014. Biopharmaceutical Process Optimization with Simulation and Scheduling Tools. Bioengineering 1, 154-187. doi:10.3390/bioengineering1040154

Purohit, P., Fischer, D.G., 2014. Second-generation biofuel potential in India: Sustainability and Cost Considerations. Report from UNEP. Laxenburg, Austria.

Ramey, D.E., 1998. Continuous two stage, dual path anaerobic fermentation of butanol and 
other organic solvents using two different strains of bacteria. Patent Number-5753474.

Rivard, C.J., Grohmann, K., 1991. DEGRADATION OF FURFURAL (2-FURALDEHYDE) TO METHANE AND CARBON-DIOXIDE BY AN ANAEROBIC CONSORTIUM. Appl. Biochem. Biotechnol. 28-9, 285-295. doi:10.1007/BF02922608

Sánchez-Segado, S., Lozano, L.J., de Los Ríos, a P., Hernández-Fernández, F.J., Godínez, C., Juan, D., 2012. Process design and economic analysis of a hypothetical bioethanol production plant using carob pod as feedstock. Bioresour. Technol. 104, 324-8.

doi:10.1016/j.biortech.2011.10.046

Sauer, M., Porro, D., Mattanovich, D., Branduardi, P., 2008. Microbial production of organic acids: expanding the markets. Trends Biotechnol. 26, 100-8. doi:10.1016/j.tibtech.2007.11.006

Shafiei, M., Kabir, M.M., Zilouei, H., Sárvári Horváth, I., Karimi, K., 2013. Technoeconomical study of biogas production improved by steam explosion pretreatment. Bioresour. Technol. 148, 53-60. doi:10.1016/j.biortech.2013.08.111

Shanmugam, S.R., Chaganti, S.R., Lalman, J.A., Heath, D.D., 2014. Effect of inhibitors on hydrogen consumption and microbial population dynamics in mixed anaerobic cultures. Int. J. Hydrogen Energy 39, 249-257. doi:10.1016/j.ijhydene.2013.10.084

Sikder, J., Roy, M., Dey, P., Pal, P., 2012. Techno-economic analysis of a membraneintegrated bioreactor system for production of lactic acid from sugarcane juice. Biochem. Eng. J. 63, 81-87. doi:10.1016/j.bej.2011.11.004

Stams, A.J.M., Elferink, S.J.W.H., Westermann, P., 2003. Metabolic Interactions between Methanogenic Consortia and Anaerobic Respiring Bacteria, in: Ahring, B.K. (Ed.), Biomethanation I. Springer-Verlag, pp. 43-45.

Statistik, D., 2014. Halm [WWW Document]. 
1 Taherzadeh, M.J., Karimi, K., 2008. Pretreatment of lignocellulosic wastes to improve ethanol and biogas production: a review., International journal of molecular sciences. doi:10.3390/ijms9091621

Wang, X., Wang, Y., Zhang, X., Feng, H., Xu, T., 2013. In-situ combination of fermentation and electrodialysis with bipolar membranes for the production of lactic acid: continuous operation. Bioresour. Technol. 147, 442-8. doi:10.1016/j.biortech.2013.08.045

Wooley, R., Ruth, M., Ibsen, K., Jechura, J., Neeves, K., Sheehan, J., Wallace, B., 2002. Lignocellulosic biomass to ethanol process design and economics utilizing co-current dilute acid prehydrolysis and enzymatic hydrolysis for Corn Stover, NREL/TP-51032438. 1617 Cole Boulevard, Golden, Colorado 80401-3393.

Zhang, C., Yang, H., Yang, F., Ma, Y., 2009. Current progress on butyric acid production by fermentation. Curr. Microbiol. 59, 656-663. doi:10.1007/s00284-009-9491-y

Zhu, Y., Liu, X., Yang, S.-T., 2005. Construction and characterization of pta gene-deleted mutant of Clostridium tyrobutyricum for enhanced butyric acid fermentation. Biotechnol. Bioeng. 90, 154-66. doi:10.1002/bit.20354

Zidwick, M.J., Chen, Z.J., Rogers, P., 2013. Organic Acid and Solven Production: Propionic and Butyric Acids and Ethanol, in: Rosenberg, E., DeLong, E.F., Lory, S., Stackebrandt, E., Thompson, F. (Eds.), The Prokaryotes. Springer Berlin Heidelberg, Berlin, Heidelberg, pp. 135-167. doi:10.1007/978-3-642-31331-8_385

Zigova, J., Ernest, S, Vandak D, S.S., 1999. Butyric acid production by Clostridium butyricum with integrated extraction and pertraction. Process Biochem. 34, 835-843.

Zigova, J., Sturdik, E., 2000. Advances in biotechnological production of butyric acid. J. Ind. Microbiol. Biotechnol. doi:10.1038/sj.jim.2900795

Öhrman, O.G.W., Weiland, F., Pettersson, E., Johansson, A.-C., Hedman, H., Pedersen, M., 
2013. Pressurized oxygen blown entrained flow gasification of a biorefinery lignin residue. Fuel Process. Technol. 115, 130-138. doi:10.1016/j.fuproc.2013.04.009 
Table 1. Major components of wheat straw as percentage of dry matter.

\begin{tabular}{lrrr}
\hline Polymers & (Petersen et al., 2009) & (Hansen et al., 2013) & (Georgieva et al., 2008) \\
\hline & & & 41.8 \\
Cellulose & 35.0 & 42.3 & 25.3 \\
Hemicellulose & 22.3 & 24.0 & 23.4 \\
Lignin & 15.6 & 22.4 & 5.6 \\
Ash & 6.5 & 5.1 & Not reported \\
Others & 20.9 & Not reported &
\end{tabular}

5

6 
1 Table 2: Stoichiometry of reactions and conversion efficiency assumed for the different unit

2 processes involved in the present process model.

\begin{tabular}{rr}
\hline Reactions & $\begin{array}{r}\text { Fraction (\%) } \\
\text { converted to }\end{array}$ \\
product
\end{tabular}

Pretreatment (Wet Explosion)

$\begin{array}{ll}\text { Cellulose }+1.11 \mathrm{H}_{2} \mathrm{O} \rightarrow 1.11 \text { Glucose } & 6.00\end{array}$

$\begin{array}{ll}\text { Cellulose } \rightarrow \mathrm{HMF}+3 \mathrm{H}_{2} \mathrm{O} & 0.09\end{array}$

Hemicellulose $+0.136 \mathrm{H}_{2} \mathrm{O} \rightarrow 1.136$ Xylose $\quad 61.56$

Hemicellulose $+0.136 \mathrm{H}_{2} \mathrm{O} \rightarrow 1.136$ Arabinose $\quad 4.44$

Hemicellulose $\rightarrow 0.64$ Furfural $+0.36 \mathrm{H}_{2} \mathrm{O}$

Enzymatic hydrolysis

Cellulose $+1.11 \mathrm{H}_{2} \mathrm{O} \rightarrow 1.11$ Glucose $\quad 85.00$

Hemicellulose $+0.136 \mathrm{H}_{2} \mathrm{O} \rightarrow 1.136$ Xylose $\quad 60.00$

Fermentation

Glucose +0.63 Xylose $\rightarrow 0.24$ Acetic acid +1.47 Butyric 100

acid $+2.79 \mathrm{CO}_{2}+2.64 \mathrm{H}_{2}+0.14 \mathrm{H}_{2} \mathrm{O}$

Methanogenesis

$\begin{array}{ll}\text { Acetate } \rightarrow \text { Methane }+\mathrm{CO}_{2} & 100\end{array}$

Hydrogen $+\mathrm{CO}_{2} \rightarrow$ Methane $+\mathrm{H}_{2} \mathrm{O} \quad 100$ 
2 Table 3: Detailed operational parameters and technical characteristics of the unit operations and

3 processes used in this model.

\begin{tabular}{|c|c|c|c|}
\hline Unit Name & Type & $\begin{array}{l}\text { Material of } \\
\text { Construction }\end{array}$ & Details \\
\hline WSH-101 & Washer & CS & Silica removal efficiency $>99 \%$ \\
\hline SR-101 & Shredder & CS & $0.01 \mathrm{~kW} /(\mathrm{kg} / \mathrm{h})$ Specific power \\
\hline V-105 & $\begin{array}{l}\text { Sulfuric acid } \\
\text { storage tank }\end{array}$ & SS316 & $\begin{array}{l}\text { Residence time } 5 \text { days, working to vessel volume } \\
\text { ratio } 90 \%\end{array}$ \\
\hline GP-101 & $\begin{array}{l}\text { Gear pump to } \\
\text { transport straw } \\
\text { into pretreatment } \\
\text { reactor }\end{array}$ & SS316 & Pressure change 5 bar, power efficiency 70\% \\
\hline PFR-102 & $\begin{array}{l}\text { Pretreatment } \\
\text { reactor }\end{array}$ & SS316 & $\begin{array}{l}\text { Residence time } 15 \mathrm{~min} \text {, temperature } 150{ }^{0} \mathrm{C} \text {, total } \\
\text { solids } 15 \% \text { specific power } 0.1 \mathrm{~kW} / \mathrm{m}^{3}\end{array}$ \\
\hline V-101 & Flash drum & CS & $\begin{array}{l}\text { Pressure } 1 \text { bar, residence time } 5 \text { min, work to } \\
\text { vessel volume ration } 60 \% \text {, temperature } 30^{\circ} \mathrm{C}\end{array}$ \\
\hline V-107 & $\begin{array}{l}\text { PH cotrol before } \\
\text { saccharification }\end{array}$ & CS & $\begin{array}{l}\text { residence time } 0.5 \mathrm{~h}, 0.1 \mathrm{~kW} /(\mathrm{kg} / \mathrm{h}) \text { Specific } \\
\text { power, } 0.01 \% \text { excess } \mathrm{NaOH}\end{array}$ \\
\hline V-106 & Enzyme tank & SS316 & $\begin{array}{l}\text { Residence time } 5 \text { days, working to vessel volume } \\
\text { ratio } 90 \%\end{array}$ \\
\hline $\mathrm{R}-101$ & $\begin{array}{l}\text { Sccarification } \\
\text { reactor }\end{array}$ & SS316 & $\begin{array}{l}\text { Residence time } 24 \mathrm{~h} \text {, temperature } 32^{0} \mathrm{C} \text {, specific } \\
\text { power } 0.1 \mathrm{~kW} / \mathrm{m} 3 \text {, total solids } 15 \% \text {, working to } \\
\text { vessel volume ratio } 90 \%\end{array}$ \\
\hline BF-101 & $\begin{array}{l}\text { Belt filter for } \\
\text { soilds seperation }\end{array}$ & CS & $\begin{array}{l}\text { Solids in cake } 50 \% \text {, flow per unit belt width } \\
\text { 10L/min-m, solids loading } 3000(\mathrm{~kg} / \mathrm{h}) / \mathrm{m}\end{array}$ \\
\hline V-104 & Neutralizer & CS & $\begin{array}{l}\text { residence time } 0.5 \mathrm{~h}, 0.1 \mathrm{~kW} /(\mathrm{kg} / \mathrm{h}) \text { Specific } \\
\text { power, } 0.01 \% \text { excess } \mathrm{KOH}\end{array}$ \\
\hline ST-101 & Heat sterilizer & SS316 & $\begin{array}{l}\text { Sterilization temperature } 140^{\circ} \mathrm{C} \text {, exit temperature } \\
41^{0} \mathrm{C}\end{array}$ \\
\hline $\mathrm{R}-102$ & $\begin{array}{l}\text { Fermentation } \\
\text { reactor }\end{array}$ & SS316 & $\begin{array}{l}\text { Residence time } 1.28 \text { (for } \mathrm{S} 2 \text { ) and } 2 \text { (for } \mathrm{S} 1 \text { ) days, } \\
\text { temperature } 37^{0} \mathrm{C} \text {, specific power } 0.1 \mathrm{~kW} / \mathrm{m}^{3} \text {, } \\
\text { working to vessel volume ratio } 90 \% \text {, effluent } \\
\text { split } 0.88 \% \text { of the total recirculation }\end{array}$ \\
\hline V-108 & Dialyzate tank & SS316 & $\begin{array}{l}\text { Residence time } 1 \text { day, working to vessel volume } \\
\text { ratio } 90 \%\end{array}$ \\
\hline G2 & REED+EDBM & CS & $\begin{array}{l}\text { REED ( power } 0.1547 \mathrm{~kW} /(\mathrm{kg} / \mathrm{h}) \text {, current } \\
\text { efficiency } 0.7 \text {, current density 500A } / \mathrm{m}^{2} \text {, average } \\
\text { recovery 92\%); EDBM ( power } 0.1547 \\
\mathrm{~kW} /(\mathrm{kg} / \mathrm{h}) \text {, current efficiency } 0.72 \text {, current } \\
\text { density } 1000 \mathrm{~A} / \mathrm{m}^{2} \text {, average recovery } 100 \% \text { ), } \\
\text { butyric acid final concentration } 5.5 \%\end{array}$ \\
\hline V-103 & Acid storage tank & SS316 & $\begin{array}{l}\text { Residence time } 2 \mathrm{~h} \text {, working to vessel volume } \\
\text { ratio } 90 \%\end{array}$ \\
\hline MSX-101 & $\begin{array}{l}\text { Mixer-settler } \\
\text { extractor }\end{array}$ & SS316 & $\begin{array}{l}\text { Mixer residence time } 0.5 \mathrm{~h} \text {, settler residence time } \\
\text { 1h, temperature } 32{ }^{0} \mathrm{C} \text {, specific power }\end{array}$ \\
\hline
\end{tabular}




\section{$0.5 \mathrm{~kW} /(\mathrm{kg} / \mathrm{h})$}

\begin{tabular}{|c|c|c|c|}
\hline C-101 & $\begin{array}{l}\text { Distillation } \\
\text { column }\end{array}$ & CS & $\begin{array}{l}\text { Number of stages } 25 \text {, Reboiler temperature } \\
175^{\circ} \mathrm{C} \text {, condenser temperature } 165^{\circ} \mathrm{C} \text {, column } \\
\text { pressure } 1 \text { bar, max dia } 2 \mathrm{~m} \text {, stage height } 0.4 \mathrm{~m}\end{array}$ \\
\hline PM-101 & $\begin{array}{l}\text { Boiler feed water } \\
\text { pump }\end{array}$ & SS316 & Pressure change 94 bar, power efficiency 70\% \\
\hline SG-101 & Steam generator & CS & $\begin{array}{l}\text { Excess oxygen } 10 \% \text {, overall heat loss } 5 \% \text {, flue } \\
\text { gas exit temperature } 120{ }^{0} \mathrm{C}\end{array}$ \\
\hline $\mathrm{T}-101$ & Steam turbine & CS & $\begin{array}{l}\text { Power generator efficiency } 90 \% \text { of shaft power, } \\
3 \text { stages (high pressure steam } 180^{\circ} \mathrm{C} \text {, low } \\
\text { pressure steam } 150^{\circ} \mathrm{C} \text { and bleed) }\end{array}$ \\
\hline
\end{tabular}


2 Table 4. Raw material prices used in this model.

\begin{tabular}{|c|c|c|c|}
\hline Item Name & Price $^{\mathrm{a}}$ & Unit & Reference \\
\hline Wheat straw & 0.0125 & $\$ / \mathrm{kg}$ & (Mangaraj and Kulkarni, 2011) \\
\hline Enzyme & 0.571 & $\$ / \mathrm{kg}$ & (Kumar and Murthy, 2011) \\
\hline Sulfuric acid & 0.035 & $\$ / \mathrm{kg}$ & (Kumar and Murthy, 2011) \\
\hline $\mathrm{NaOH}$ & 0.45 & $\$ / \mathrm{kg}$ & (Kumar and Murthy, 2011) \\
\hline $\mathrm{KOH}$ & 0.189 & $\$ / \mathrm{kg}$ & (Ljunggren et al., 2011) \\
\hline Urea & 0.649 & $\$ / \mathrm{kg}$ & (Sánchez-Segado et al., 2012) \\
\hline Phosphate & 0.891 & $\$ / \mathrm{kg}$ & (Sánchez-Segado et al., 2012) \\
\hline
\end{tabular}

${ }^{\mathrm{a}}$ Conversion factor: 1 US $\$=0.74$ EUR

3 
2 Table 5: Summary of the economics and mass and energy requirements for scenarios S1 and S2

\begin{tabular}{|c|c|c|c|}
\hline & S1 & S2 & Unit \\
\hline Total Capital Investment & 47.71 & 53.68 & million \$ \\
\hline Capital Investment Charged to this project (100\%) & 47.71 & 53.68 & million \$ \\
\hline Operating Cost & 27.52 & 33.12 & million $\$ / y r$ \\
\hline Credits & 4.65 & 5.56 & million \$/yr \\
\hline Net Operating Cost & 22.87 & 27.56 & million $\$ / y r$ \\
\hline Revenues & 35.05 & 39.46 & million $\$ / y r$ \\
\hline Unit Production Cost & 2.75 & 3.31 & $\$ / \mathrm{kg} \mathrm{MP}$ \\
\hline Net Unit Production Cost & 2.29 & 2.76 & $\$ / \mathrm{kg} \mathrm{MP}$ \\
\hline Unit Production Revenue & 3.51 & 3.95 & $\$ / \mathrm{kg} \mathrm{MP}$ \\
\hline Gross Margin & 34.75 & 30.16 & $\%$ \\
\hline Return On Investment & 23.35 & 21.28 & $\%$ \\
\hline Payback Time & 4.28 & 4.7 & years \\
\hline IRR (After Taxes) & 14.92 & 12.42 & $\%$ \\
\hline NPV (at 7.0\% Interest) & 28.56 & 21.11 & million \$ \\
\hline Cost Basis Annual Rate & 10000.07 & 10000.04 & tonnes $\mathrm{MP} / \mathrm{yr}$ \\
\hline Feed stock (wheat straw) & 46150.21 & 51611.59 & tonnes/yr \\
\hline Efficiency (mass MP/mass wheat straw) & 0.22 & 0.19 & \\
\hline Power (electricity) demand & 34831.14 & 38960.81 & MW-h/yr \\
\hline Net steam demand & 17553.71 & 19630.00 & tonnes/yr \\
\hline Net steam (high P) demand & 162987.52 & 201139.12 & tonnes/yr \\
\hline
\end{tabular}

$3 \mathrm{MP}=$ Total flow of acid or mixed acids as main product

$4 \quad$ IRR $=$ Internal Rate of Return

$5 \quad \mathrm{NPV}=$ Net Present Value 
2 Table 6: Direct fixed cost summary (year 2014 prices in million \$) for scenarios S1 and S2.

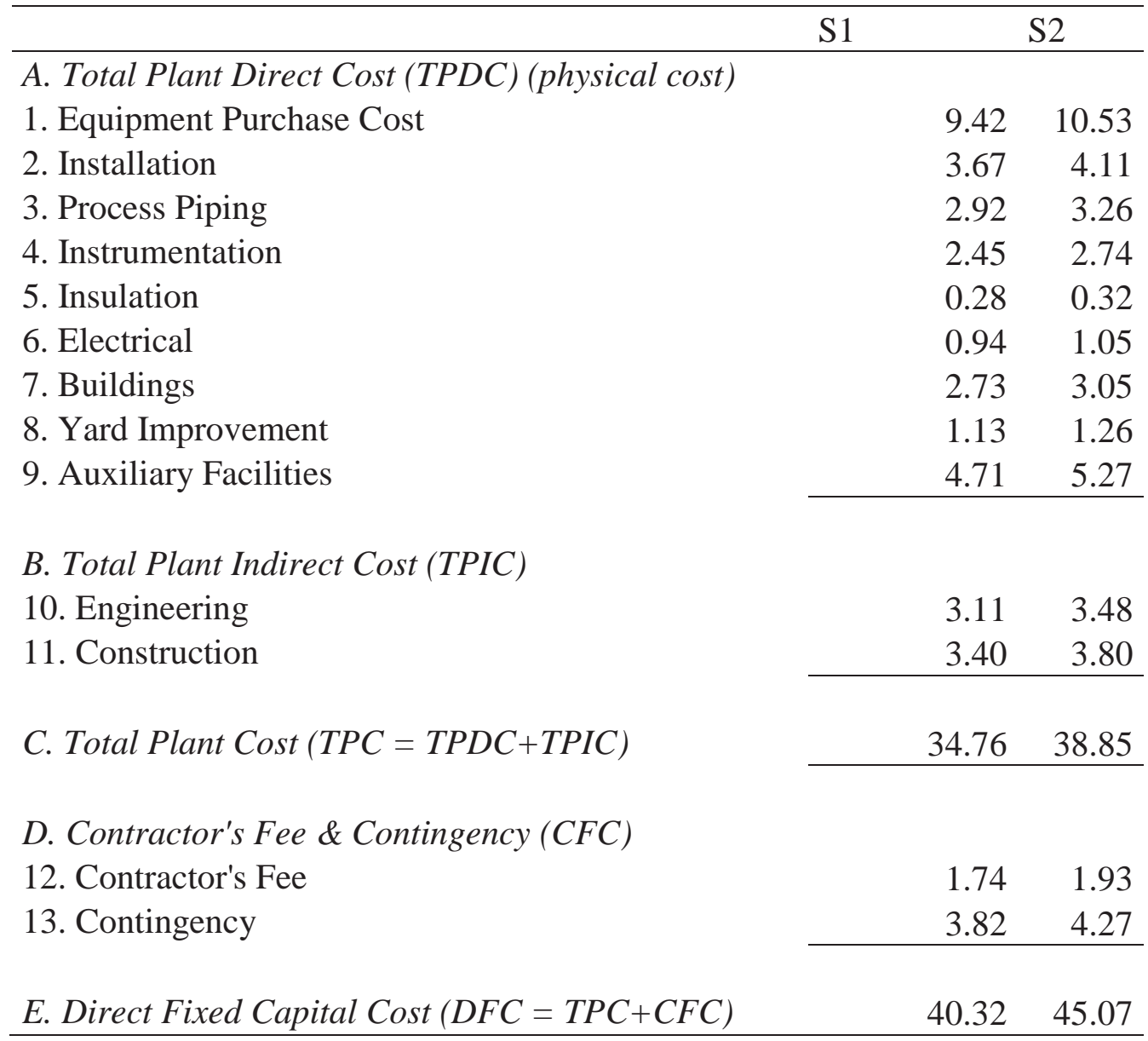


2 Table 7: Annual operating costs (million \$) distribution for an annual production of 10,000 tonnes

3 MP for both scenarios (S1, S2) for the year 2014.

\begin{tabular}{|c|c|c|c|c|}
\hline & S1 & $\%$ of Total & $\mathrm{S} 2$ & $\%$ of Total \\
\hline \multicolumn{5}{|l|}{ Labor } \\
\hline Operator & 0.73 & $2.65 \%$ & 1.07 & $3.23 \%$ \\
\hline \multicolumn{5}{|l|}{ Raw Materials } \\
\hline Enzyme mix & 0.40 & $1.45 \%$ & 0.46 & $1.39 \%$ \\
\hline Wheat straw (86\%DM) & 0.55 & $2.00 \%$ & 0.62 & $1.87 \%$ \\
\hline $\mathrm{KOH}$ & 0.002 & $0.01 \%$ & 0.002 & $0.01 \%$ \\
\hline Octanol,1 & 0.04 & $0.15 \%$ & 0.05 & $0.15 \%$ \\
\hline $\mathrm{K}_{2} \mathrm{HPO}_{4}$ & 0.14 & $0.51 \%$ & 0.15 & $0.45 \%$ \\
\hline $\mathrm{NaOH}$ & 0.28 & $1.02 \%$ & 0.32 & $0.97 \%$ \\
\hline $\mathrm{H}_{2} \mathrm{SO}_{4}$ & 0.03 & $0.11 \%$ & 0.03 & $0.09 \%$ \\
\hline Urea & 0.70 & $2.54 \%$ & 0.80 & $2.42 \%$ \\
\hline Water & 0.07 & $0.25 \%$ & 0.08 & $0.24 \%$ \\
\hline \multicolumn{5}{|l|}{ Consumables } \\
\hline EDBM membrane & 0.68 & $2.47 \%$ & 0.77 & $2.32 \%$ \\
\hline Anion exchange membrane & 0.36 & $1.31 \%$ & 0.41 & $1.24 \%$ \\
\hline Cation exchange membrane & 0.42 & $1.53 \%$ & 0.48 & $1.45 \%$ \\
\hline $\mathrm{NaOH}^{+}$ & 0.003 & $0.01 \%$ & 0.003 & $0.01 \%$ \\
\hline \multicolumn{5}{|l|}{ Waste Disposal } \\
\hline Ash & 0.04 & $0.15 \%$ & 0.04 & $0.12 \%$ \\
\hline Wash waste water & 0.31 & $1.13 \%$ & 0.35 & $1.06 \%$ \\
\hline Effluent & 0.34 & $1.24 \%$ & 0.39 & $1.18 \%$ \\
\hline Utility & & $0.00 \%$ & & \\
\hline Std Power & 2.41 & $8.76 \%$ & 2.76 & $8.33 \%$ \\
\hline Steam & 0.21 & $0.76 \%$ & 0.23 & $0.69 \%$ \\
\hline High Pressure steam & 9.41 & $34.19 \%$ & 11.84 & $35.75 \%$ \\
\hline Cooling Water & 2.61 & $9.48 \%$ & 3.28 & $9.90 \%$ \\
\hline Facility-Dependent & 7.81 & $28.38 \%$ & 8.73 & $26.36 \%$ \\
\hline Laboratory/QC/QA & 0.11 & $0.40 \%$ & 0.16 & $0.48 \%$ \\
\hline TOTAL & 27.52 & & 33.12 & \\
\hline
\end{tabular}

$4 \$$ For the sake of calculation $\mathrm{NaOH}$ used in REED and EDBM system is considered as consumable 5 
2 Table 8: Economic summary and operating cost distribution (year 2014) for S1 and S2 when

3 considering in-house steam generation by CHP unit.

\begin{tabular}{lrr}
\hline & S1 & S2 \\
\hline Total Capital Investment (million\$) & 49.04 & 54.14 \\
Operating Cost (million\$) & 19.34 & 22.99 \\
Unit Production Cost (\$/kgMP) & 1.84 & 2.16 \\
Direct Fixed Capital (million\$) & 42.53 & 47.24 \\
\hline Operating cost (2014 prices) summary (million\$) & & \\
\hline Cost Item & & \\
Raw Materials & 2.62 & 3.04 \\
Labor-Dependent & 0.73 & 1.07 \\
Depreciation & 4.04 & 4.50 \\
Other Facility-Dependent & 4.20 & 4.66 \\
Laboratory/QC/QA & 0.11 & 0.16 \\
Consumables & 1.54 & 2.62 \\
Waste Treatment/Disposal & 0.75 & 0.87 \\
Utilities & 5.26 & 6.36 \\
\hline Total & 19.24 & 23.27 \\
\hline
\end{tabular}


2 Table A1: Purchase cost (year 2014) and size or capacity of equipment unit used in this model for 310,000 tonnes MP production.

\begin{tabular}{|c|c|c|c|c|}
\hline & & S1 & S2 & S2 \\
\hline Name & Description & Cost $(\$)$ & Description & Cost $(\$)$ \\
\hline \multicolumn{5}{|c|}{ Feed stock handling } \\
\hline \multirow[t]{2}{*}{ WSH-101 } & Washer (Bulk Flow) & 1000 & Washer (Bulk Flow) & 1000 \\
\hline & Size/Capacity = 5.56 MT/h & & Size $/$ Capacity = 6.29 MT/h & \\
\hline \multirow[t]{2}{*}{ SR-101 } & Shredder & 190000 & Shredder & 204000 \\
\hline & Size/Capacity = $5.52 \mathrm{MT} / \mathrm{h}$ & & Size $/$ Capacity = $6.24 \mathrm{MT} / \mathrm{h}$ & \\
\hline \multicolumn{5}{|l|}{ Pretreatment } \\
\hline \multirow[t]{2}{*}{ V-105 } & Vertical-On-Legs Tank & 22000 & Vertical-On-Legs Tank & 24000 \\
\hline & Vessel Volume $=7.12 \mathrm{~m} 3$ & & Vessel Volume $=8.05 \mathrm{~m} 3$ & \\
\hline \multirow[t]{2}{*}{ GP-101 } & Gear Pump & 16000 & Gear Pump & 18000 \\
\hline & Pump Power $=6.48 \mathrm{~kW}$ & & Pump Power $=7.33 \mathrm{~kW}$ & \\
\hline \multirow[t]{2}{*}{ PFR-102 } & Plug Flow Reactor & 286000 & Plug Flow Reactor & 308000 \\
\hline & Vessel Volume $=1.24 \mathrm{~m} 3$ & & Vessel Volume $=1.40 \mathrm{~m} 3$ & \\
\hline HX-104 & $\begin{array}{l}\text { Heat Exchanger } \\
\text { Heat Exchange Area }=99.60 \mathrm{~m} 2\end{array}$ & 2032000 & $\begin{array}{l}\text { Heat Exchanger } \\
\text { Heat Exchange Area = } \\
94.83 \mathrm{~m} 2\end{array}$ & 2337000 \\
\hline \multirow[t]{2}{*}{ V-101 } & Flash Drum & 2000 & Flash Drum & 2000 \\
\hline & Vessel Volume $=4507.80 \mathrm{~L}$ & & Vessel Volume $=5096.95 \mathrm{~L}$ & \\
\hline \multicolumn{5}{|l|}{ Saccharification } \\
\hline \multirow[t]{2}{*}{ V-107 } & Neutralizer & 89000 & Neutralizer & 95000 \\
\hline & Vessel Volume $=18.10 \mathrm{~m} 3$ & & Vessel Volume $=20.47 \mathrm{~m} 3$ & \\
\hline \multirow[t]{2}{*}{ V-106 } & Vertical-On-Legs Tank & 11000 & Vertical-On-Legs Tank & 12000 \\
\hline & Vessel Volume $=11.96 \mathrm{~m} 3$ & & Vessel Volume $=13.52 \mathrm{~m} 3$ & \\
\hline R-101 & $\begin{array}{l}\text { Stirred Reactor } \\
\text { Vessel Volume }=872.42 \mathrm{~m} 3\end{array}$ & 355000 & $\begin{array}{l}\text { Stirred Reactor } \\
\text { Vessel Volume = } 986.45 \\
\mathrm{m3}\end{array}$ & 382000 \\
\hline \multirow[t]{2}{*}{ BF-101 } & Belt Filter & 274000 & Belt Filter & 276000 \\
\hline & Belt Width $=0.54 \mathrm{~m}$ & & Belt Width $=0.61 \mathrm{~m}$ & \\
\hline \multicolumn{5}{|c|}{ Fermentation and seperation } \\
\hline \multirow[t]{2}{*}{ V-104 } & Neutralizer & 84000 & Neutralizer & 90000 \\
\hline & Vessel Volume $=16.53 \mathrm{~m} 3$ & & Vessel Volume $=18.70 \mathrm{~m} 3$ & \\
\hline ST-101 & $\begin{array}{l}\text { Heat Sterilizer } \\
\text { Rated Throughput }=29.89 \mathrm{~m} 3 / \mathrm{h}\end{array}$ & 722000 & $\begin{array}{l}\text { Heat Sterilizer } \\
\text { Rated Throughput }=33.80 \\
\text { m3/h }\end{array}$ & 750000 \\
\hline R-102 & $\begin{array}{l}\text { Stirred Reactor } \\
\text { Vessel Volume }=1030.02 \mathrm{~m} 3\end{array}$ & 392000 & $\begin{array}{l}\text { Stirred Reactor } \\
\text { Vessel Volume = } 1746.89 \\
\text { m3 }\end{array}$ & 539000 \\
\hline V-108 & $\begin{array}{l}\text { Vertical-On-Legs Tank } \\
\text { Vessel Volume }=353.49 \mathrm{~m} 3\end{array}$ & 165000 & $\begin{array}{l}\text { Vertical-On-Legs Tank } \\
\text { Vessel Volume = } 401.63 \\
\text { m3 }\end{array}$ & 176000 \\
\hline REED+EDBM & Generic Box & 695000 & Generic Box & 767000 \\
\hline
\end{tabular}


Size/Capacity $=20638.49 \mathrm{~kg} / \mathrm{h}$

Purification

V-103

Flat Bottom Tank

Vessel Volume $=46.46 \mathrm{~m} 3$

MSX-101

HX-102

Mixer-Settler Extractor

Rated Throughput $=154333.01$

$\mathrm{L} / \mathrm{h}$

Heat Exchanger

Heat Exchange Area $=5.08 \mathrm{~m} 2$

HX-103

Heat Exchanger

Heat Exchange Area $=91.02 \mathrm{~m} 2$

C-101

Distillation Column

Column Volume $=50.99 \mathrm{~m} 3$

HX-101 Heat Exchanger

Heat Exchange Area $=71.69 \mathrm{~m} 2$

Heat and power generation

$\begin{array}{ll}\text { PM-101 } & \text { Centrifugal Pump } \\ & \text { Pump Power }=3.71 \mathrm{~kW} \\ \text { SG-101 } & \text { Steam Generator } \\ & \text { Throughput }=10116.47 \mathrm{~kg} / \mathrm{h} \\ \text { T-101 } & \begin{array}{l}\text { Multi-Stage Steam Turbine } \\ \text { Turbine Delivered Shaft Power } \\ \end{array} \\ & =16.91 \mathrm{~kW}\end{array}$

Unlisted Equipment

Total (\$)
Size/Capacity = 23339.16

$\mathrm{kg} / \mathrm{h}$

99000 Flat Bottom Tank

102000

Vessel Volume $=52.56 \mathrm{~m} 3$

325000 Mixer-Settler Extractor

350000

Rated Throughput $=$ 174515.94 L/h

21000 Heat Exchanger

Heat Exchange Area $=5.29$

$\mathrm{m} 2$

1200000 Heat Exchanger

1364000

Heat Exchange Area $=$ $96.02 \mathrm{~m} 2$

201000 Distillation Column

Column Volume $=57.71$

m3

104000 Heat Exchanger

Heat Exchange Area $=$ $80.17 \mathrm{~m} 2$

34000 Centrifugal Pump

Pump Power $=4.44 \mathrm{~kW}$

180000 Steam Generator

206000

Throughput $=12093.81$

$\mathrm{kg} / \mathrm{h}$

37000 Multi-Stage Steam Turbine Turbine Delivered Shaft Power $=21.95 \mathrm{~kW}$

39000
1884000 Unlisted Equipment

9420000 

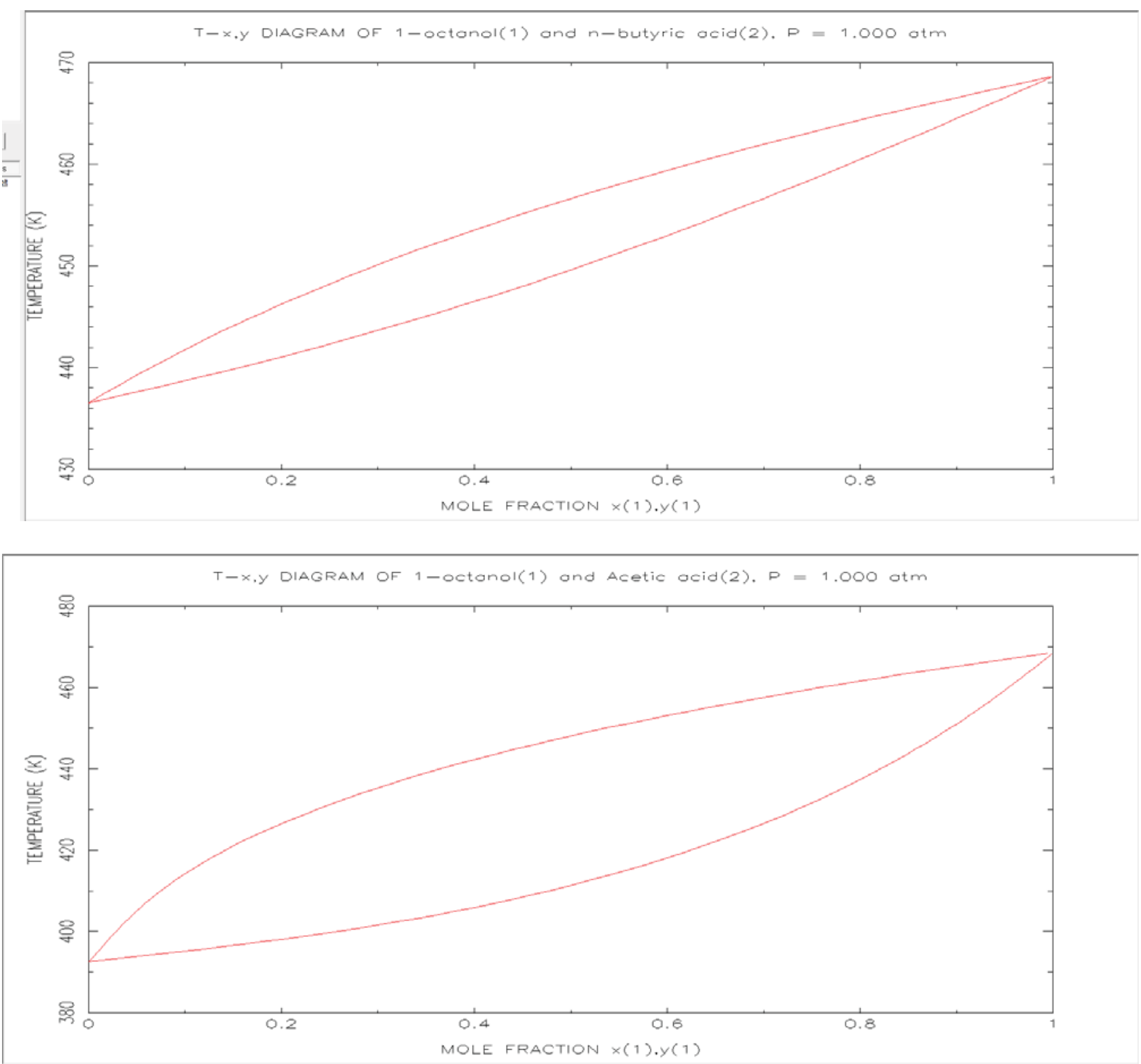

3 Figure A1. Binary phase diagrams for octanol/butyrate and octanol/acetate. No azeotrope formation is predicted. Thermodynamic model used included: equation of state, Soave-Redlich-Kwong; mixing rule, Modified Huron Vidal of $1^{\text {st }}$ order; excess Gibbs energy model, UNIFAC VLE1. 


Feed stock
handeling $\Leftrightarrow$ Pretreatment $\Rightarrow$ Saccharification $\Rightarrow \begin{gathered}\text { Fermentation } \\ \text { and seperation }\end{gathered} \Rightarrow$ Purification

Figure 1: Process flow diagram showing different process steps 


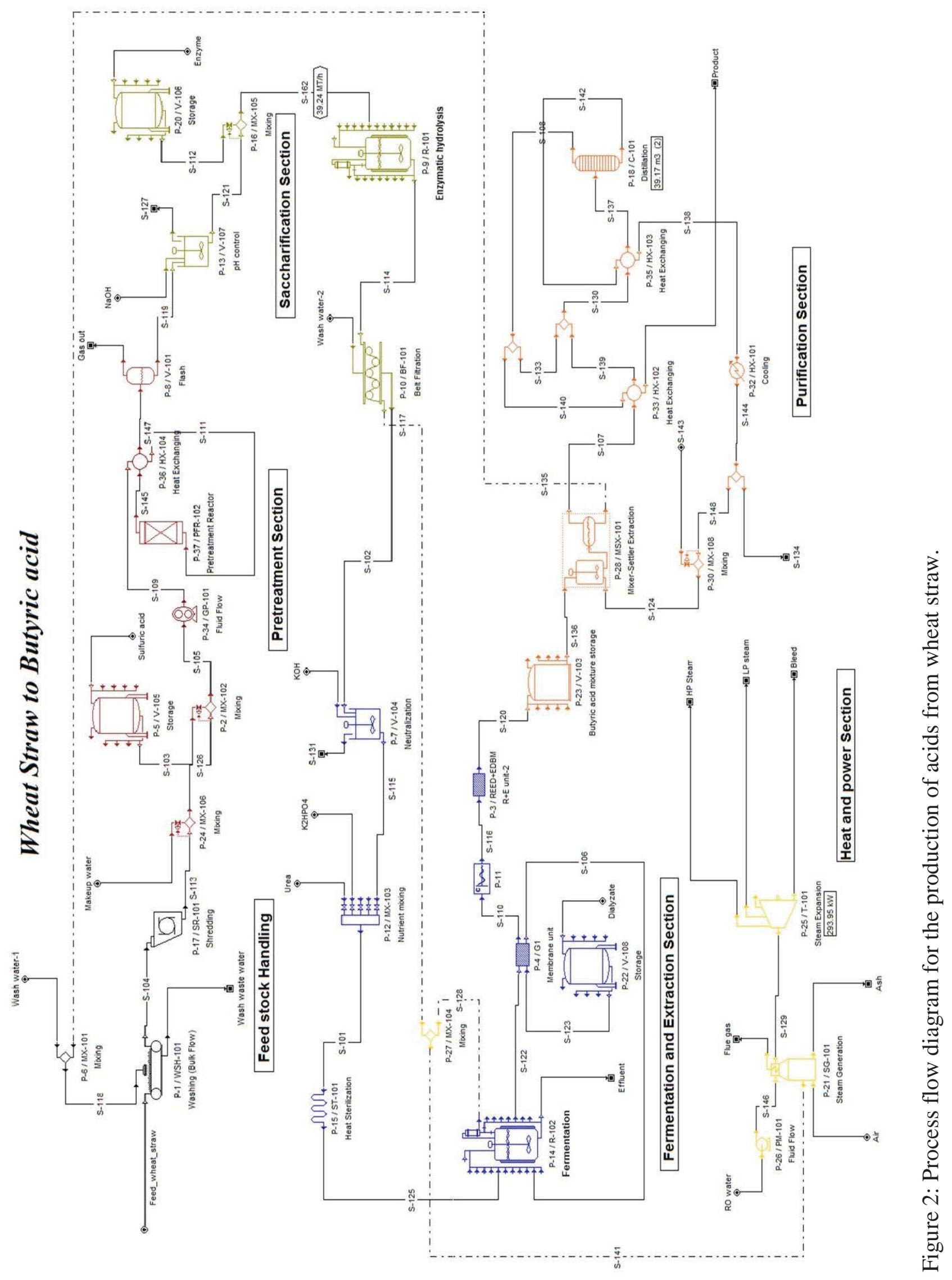



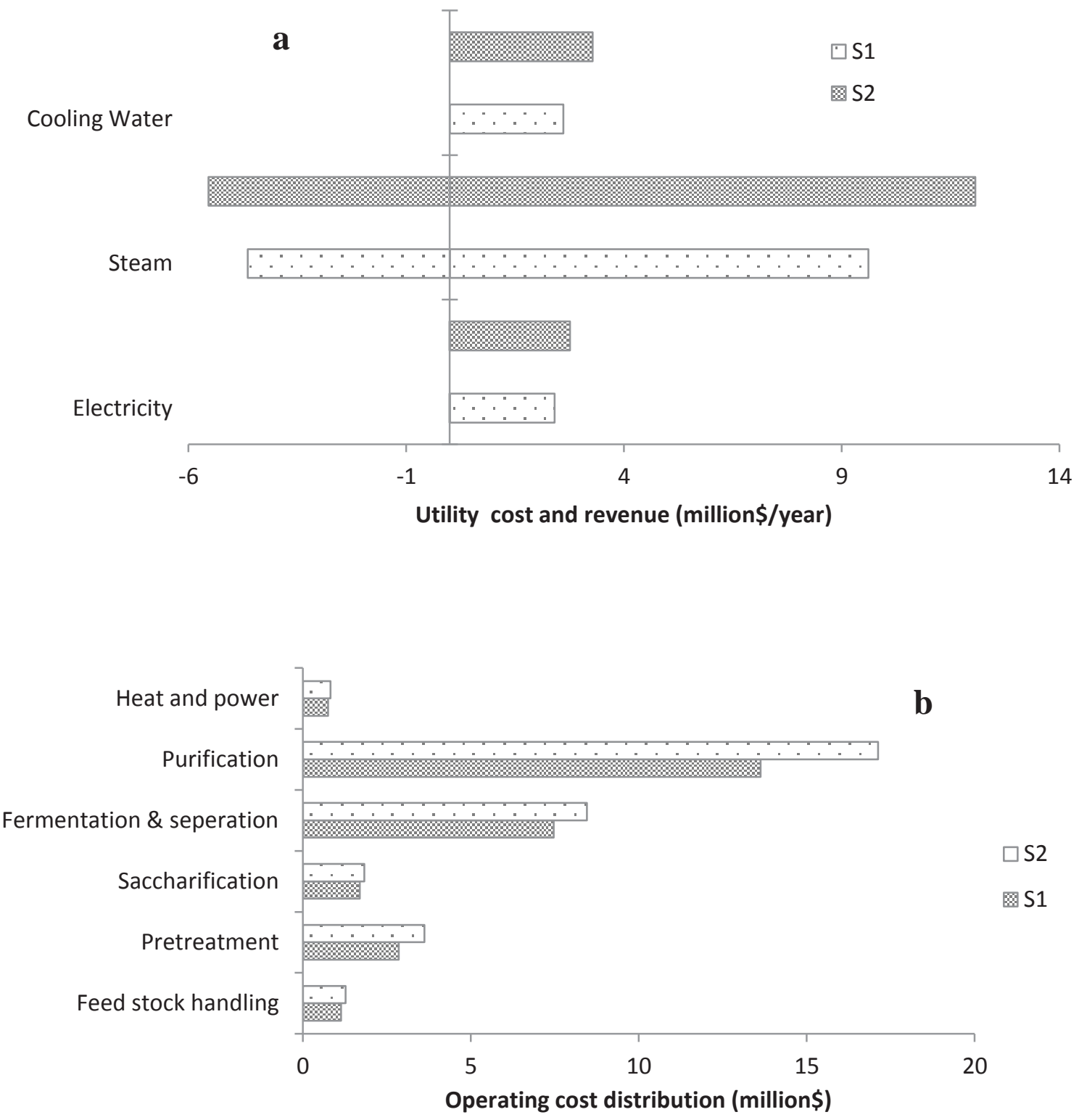

Figure 3: (a) Costs of utility and credit from heat and power section for both S1 and S2 scenarios. Credits are shown on the left side (negative) and costs are shown on the right side (positive). (b) Operating costs distributed among the six sections of the process and comparison between scenario S1 and S2. 

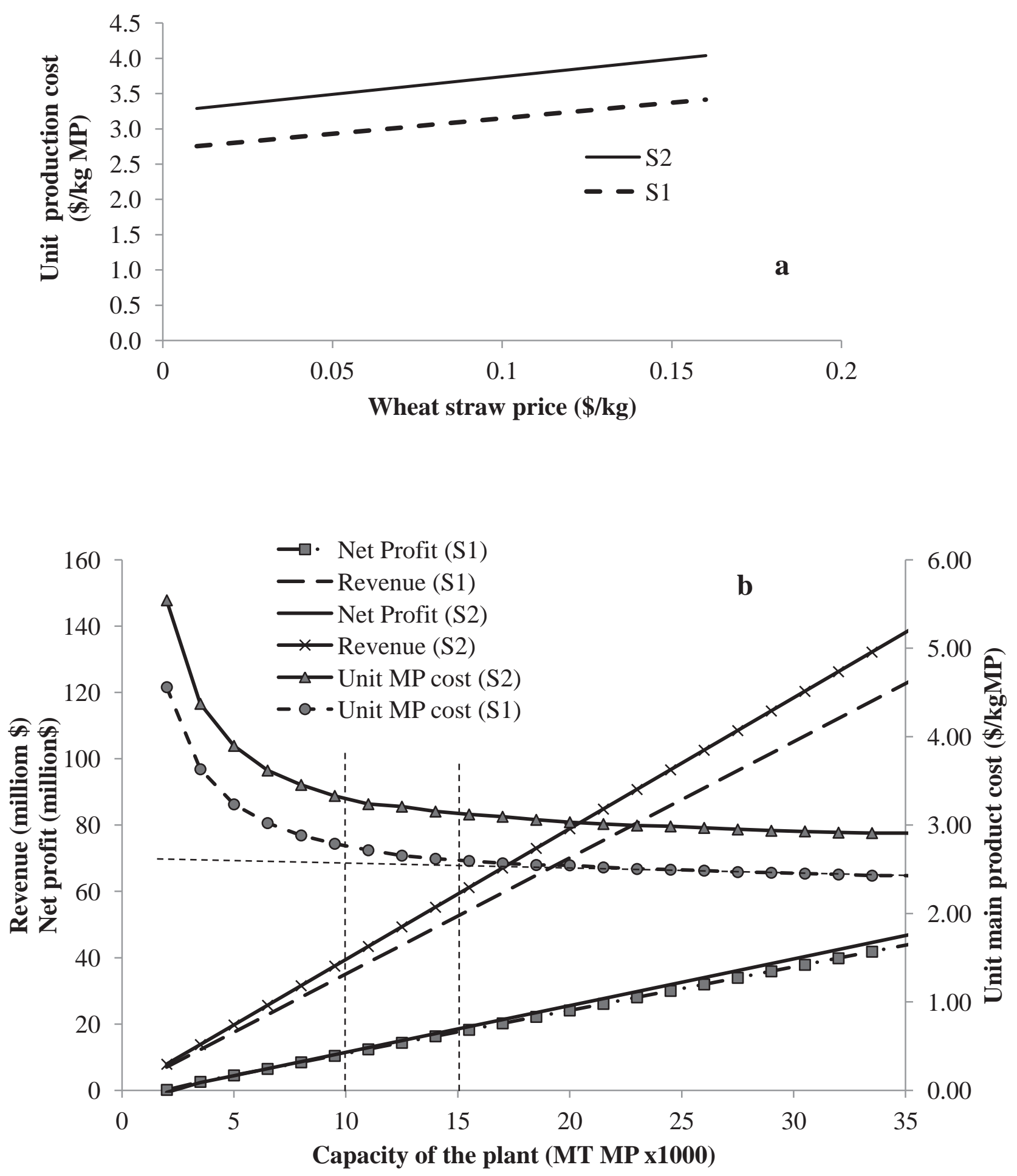

Figure 4: Effect of wheat straw price on unit production cost of MP (a) and effect of plant size on unit production cost of MP, revenue and net profit (b) for both S1 and S2 scenarios. 
(a)
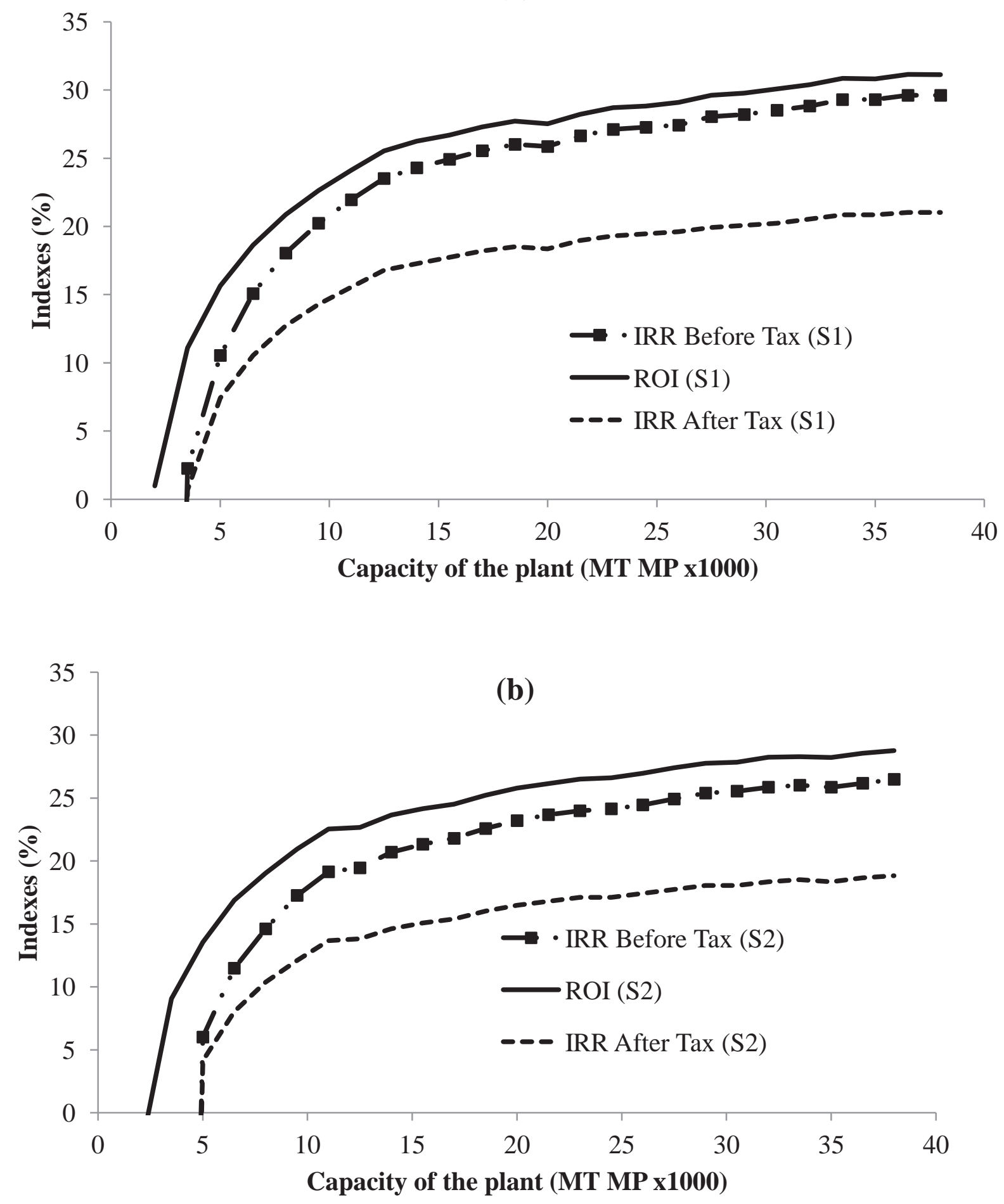

Figure 5: Effect of plant size on ROI and IRR before and after tax for scenario S1 (a) and scenario S2 (b). 


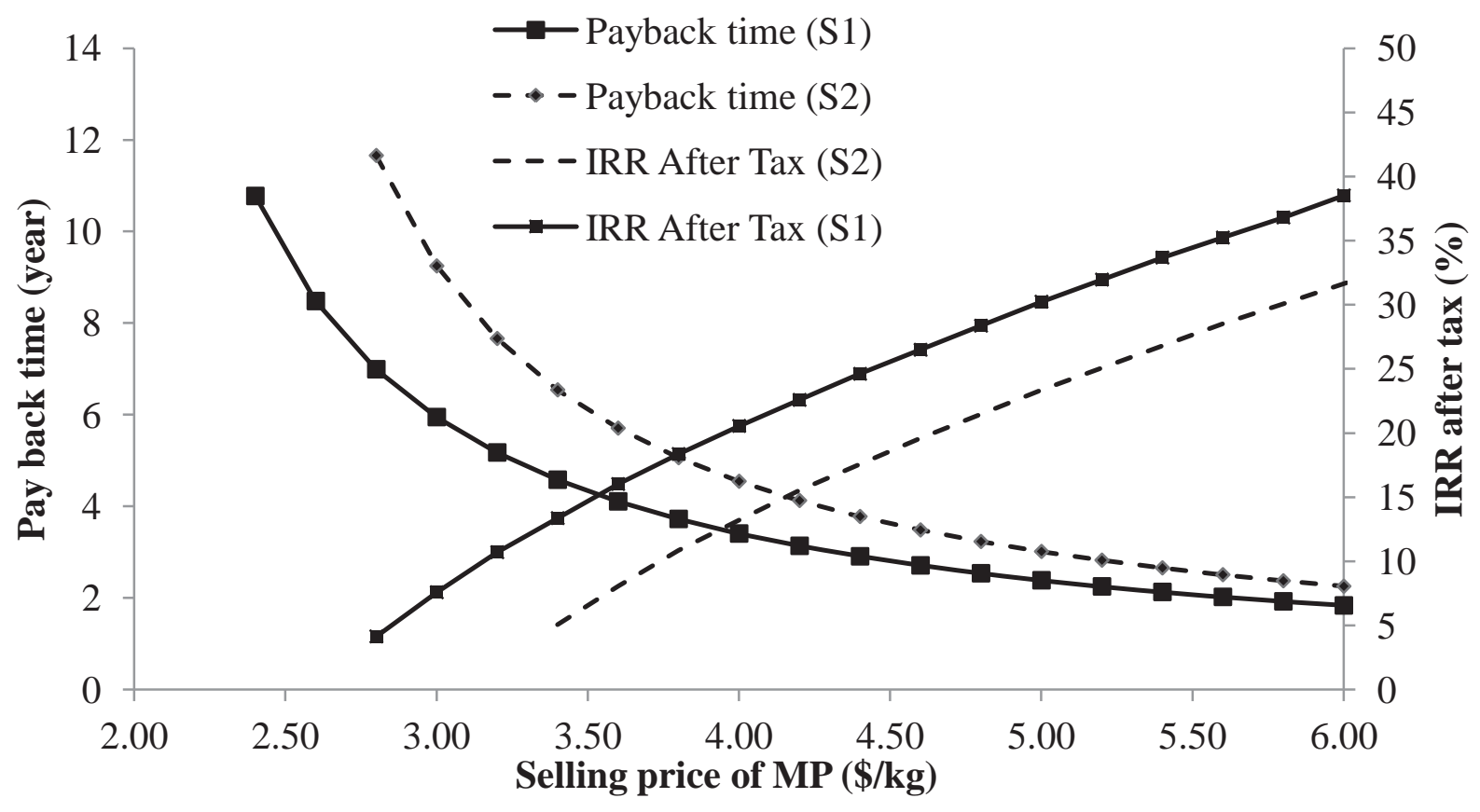

Figure 6: Effect of selling price of MP on payback time and IRR for both S1 and S2 scenarios for a plant with a capacity of 10,000 tonnes MP per year. 


\section{Figure Captions}

Figure 1: Process flow diagram showing different process steps

Figure 2: Process flow diagram for the production of acids from wheat straw.

Figure 3: (a) Costs of utility and credit from heat and power section for both S1 and S2 scenarios. Credits are shown on the left side (negative) and costs are shown on the right side (positive). (b) Operating costs distributed among the six sections of the process and comparison between scenario S1 and S2.

Figure 4: Effect of wheat straw price on unit production cost of MP (a) and effect of plant size on unit production cost, revenue and net profit (b) for both S1 and S2 scenarios.

Figure 5: Effect of plant size on ROI and IRR before and after tax for scenario S1 (a) and scenario S2 (b).

Figure 6: Effect of selling price of MP on payback time and IRR for both S1 and S2 scenarios for a plant with a capacity of 10,000 tonnes MP per year. 
Process flow diagram of S1 in SuperPro Designer format

Click here to download Supplementary Interactive Plot Data (CSV): withoutmethane-1002-dp_octanol.spf 
Process flow diagram of S2 in SuperPro Designer format

Click here to download Supplementary Interactive Plot Data (CSV): withmethane-1002-dp_octanol.spf 